Florida International University FIU Digital Commons

FIU Electronic Theses and Dissertations

University Graduate School

3-28-2013

\title{
The Great Escape: A Modern Charismatic Movement within the Presbyterian Church
}

Nicholas Edward Pearce

Florida International University, npearce@fiu.edu

DOI: $10.25148 /$ etd.FI13042319

Follow this and additional works at: https://digitalcommons.fiu.edu/etd

Part of the Religion Commons

\section{Recommended Citation}

Pearce, Nicholas Edward, "The Great Escape: A Modern Charismatic Movement within the Presbyterian Church" (2013). FIU Electronic Theses and Dissertations. 856.

https://digitalcommons.fiu.edu/etd/856

This work is brought to you for free and open access by the University Graduate School at FIU Digital Commons. It has been accepted for inclusion in FIU Electronic Theses and Dissertations by an authorized administrator of FIU Digital Commons. For more information, please contact dcc@fiu.edu. 


\title{
FLORIDA INTERNATIONAL UNIVERSITY \\ Miami, Florida
}

\section{THE GREAT ESCAPE: A MODERN CHARISMATIC MOVEMENT WITHIN THE PRESBYTERIAN CHURCH}

\author{
A thesis submitted in partial fulfillment of \\ the requirements for the degree of \\ MASTER OF ARTS \\ in \\ RELIGIOUS STUDIES \\ by
}

Nicholas Edward Pearce 
To: Kenneth G. Furton

College of Arts and Sciences

This thesis, written by Nicholas Edward Pearce, and entitled The Great Escape: A Modern Charismatic Movement within the Presbyterian Church, having been approved in respect to style and intellectual content, is referred to you for judgment.

We have read this thesis and recommend that it be approved.

Albert Wuaku

Lesley Northup

Whitney Bauman, Major Professor

Date of Defense: March 28, 2013

The thesis of Nicholas Edward Pearce is approved.

Dean Kenneth G. Furton

College of Arts and Sciences

Dean Lakshmi N. Reddi

University Graduate School

Florida International University, 2013 


\section{ACKNOWLEDGMENTS}

I have been involved with the field of Religious Studies since the first day I walked on a college campus. It is the only form of academia to which I have ever felt emotionally attached. To certain degree I have also always felt an emotional attachment to Youth Conference Ministries and the Great Escape; and I always hoped that I would someday be able to combine these two in a way that could form a union within two very disconnected portions of my mind. I never fully understood how difficult this process would be, and I would not be where I am today without the help of a few important individuals who have helped me along the way.

First off I would like to thank my professors at Florida International University. Thanks to the opportunity of working with Dr. Christine Gudorf, I was confident enough in my analytical abilities to take on the arduous challenge of attempting to academically place Youth Conference Ministries and the Great Escape. Also when I first arrived at FIU I was very confident in my understanding of both the Hebrew Bible and the New Testament. However I was in for quite the surprise when I began working with Dr. Oren B. Stier and Dr. Erik Larson, as both helped me realize how much I needed to learn before I started writing my thesis. While these three professors are not on my thesis committee, their fingerprints are definitely visible in my writings.

Secondly I would like to thank my fellow students, many of whom are also undertaking the journey that is the masters thesis along with me. Without the help of Mariana Restrepo, Daniella Vaclavik, Logan Beitman, Shivani Bothra, Sabrina Diz, Charo Valero, and Kimberly Zwez there is a chance that this process would have been too much for me to handle. All of my fellow students have been there for support, mostly 
friendly criticism, and overall friendship from the beginning; and I will forever cherish the bond I have with them.

Thirdly I need to thank the leadership of Youth Conference Ministries and the Great Escape Southwind. It would not have been possible to complete this thesis without their willingness to invite me into their organization. The same goes for the leadership of the Presbyterian Churches that helped give this thesis the perspective it needed.

It is also essential for me to thank my thesis committee, as they are truly the ones who deserve credit for helping me mold my ideas into a piece of academic work of which I can be proud. I had never worked with Dr. Lesley Northup before this process started. However if she had not stressed to me that I did not have a thesis during my initial proposal defense, I would likely still only have a case study. Also this thesis required a great deal of ethnographic research, and my abilities in the field are thanks to Dr. Albert Wuaku. Also when I was considering whom to choose as my thesis chair, I knew that I needed someone who to a certain degree understood where I was coming from both theologically and academically. That is the reason why I am so lucky to have had Dr. Whitney Bauman as my chair. Throughout my previous experiences with Dr. Bauman I always enjoyed the levity that he brought towards the academic study of Religion, and I truly hope that this thesis makes him laugh as well as think.

Finally I could not have gotten to where I am in this process without the help of my wife (depending on if you are reading this after February $23^{\text {rd }}, 2013$ ) Erika. Many called me crazy when I proposed the day before the start of the Fall 2012 semester, a decision that meant that we would be planning a wedding while I wrote my thesis. 
However throughout this process she has been nothing but supportive, and I know I could not have done it without her.

I hope all who have chosen to read this master thesis enjoy their experiences with it, as it has been one of the most difficult but fulfilling processes I have ever undertaken. 
ABSTRACT OF THE THESIS

THE GREAT ESCAPE: A MODERN CHARISMATIC MOVEMENT WITHIN THE PRESBYTERIAN CHURCH

\author{
by \\ Nicholas Edward Pearce \\ Florida International University, 2013 \\ Miami, Florida

\section{Professor Whitney Bauman, Major Professor}

The present thesis examines the relationship between Youth Conference Ministries (YCM) and the Presbyterian Church. YCM is a charismatic organization that organizes youth retreats for students in middle school and high school, with the goal of charismatically educating the youth of America. The focus of this thesis is on the Great Escape Southwind, a middle school retreat that caters to the southern portion of United States. My thesis first traces the biblical and historical underpinnings of charismatic Christianity. Next it provides an ethnographic case study of the Great Escape, focusing on its ability to foster spiritual growth of students through an enthusiastic response to the Holy Spirit. Finally it examines the relationship between YCM and the Presbyteries that populate its retreats. Overall this thesis shows how YCM provides a charismatic service to the local Presbyterian Churches, allowing for its adolescent parishioners to remain enthusiastically active as they progress towards adulthood. 


\section{TABLE OF CONTENTS}

CHAPTER

PAGE

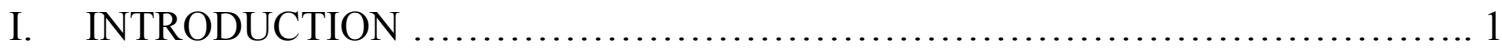

II. CHAPTER 1: THEOLOGY AND HISTORY OF THE CHARISMATIC

MOVEMENT ...................................................................... 3

III. CHAPTER TWO: CASE STUDY ON THE GREAT ESCAPE .................. 27

IV. CHAPTER 3: INTERACTIONS BETWEEN YCM AND THE PCUSA ........... 48

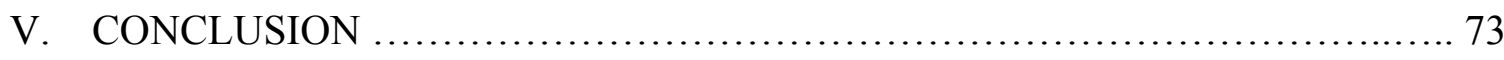

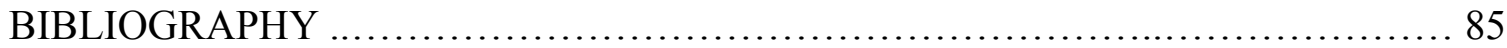




\section{INTRODUCTION}

When looking to analyze the presence of the charismatic movement within the Presbyterian Church (USA), few organizations provide a clearer picture than Youth Conference Ministries (YCM). Each summer YCM organizes a series of retreats for a variety of students who populate the Presbyterian Church in the United States. My thesis will focus primarily on the Great Escape, YCM's retreat for middle school students. More specifically it will analyze The Great Escape Southwind that takes place in Ocklawaha, Florida, that serves many PCUSA denominations in the southern region of the United States.

In order to understand the charismatic movement and more specifically YCM it will be important to firmly comprehend the biblical and historical roots of the charismatic movement, and to a lesser extent Pentecostalism. Once this has been achieved it will be necessary to trace the theological implications that accompany charismatic Christianity, and how they have interacted with the mainline denominations they have been attempting to coexist with since the 1960s. The theological implications of YCM within the PCUSA are centered in ecclesiology. By remaining in the PCUSA, they work to implement new elements of leadership into this traditional denomination. These forms of leadership affect the presbyteries by injecting elements of charismatic Christianity that are centered in an enthusiastic response to the Holy Spirit. By focusing on this enthusiastic response and working to keep it in the minds of the students who attend the Great Escape; YCM is working to place new forms of charismatic leadership into a denomination that has been the antithesis of charismatic Christianity. 
After the foundations and interactions of charismatic Christianity have been fully expounded on, I provide an ethnographic case study of the Great Escape Southwind, which takes place during the summer months in Central Florida. The case study will paint a clear picture of what exactly goes on during the retreat, and what kind of charismatic material the students who attend the retreat come into contact with. It will also lay the groundwork for ecclesiological changes YCM is implementing into the PCUSA. By examining how YCM is educating the youth of the church, the type of charismatic leadership that is being introduced into the PCUSA will be provided a clear canvass to work on.

Finally this thesis examines the interactions between YCM and the local churches they hope to serve. By examining the positive, negative, and mixed reviews from the PCUSA, it will be possible to gain a fuller understanding of what this traditional religious body thinks of the independent organization that it is attempting to work with. Overall YCM is an organization responsible for ministering to over 4,000 Presbyterian students every summer, and this thesis will provide a clear image of how YCM is affecting the future of the PCUSA. In the past the PCUSA has not viewed charismatic Christianity in a positive light. However this thesis examines how this traditional ecclesiological body is becoming more accepting of charismatic Christianity in order to revitalize the youth of their denominations. This thesis can be used as a model in order to analyze how mainline denominations interact with new and potentially unorthodox ecclesiological groups within their church. YCM provides the PCUSA with a model for how to keep their students involved as they move through adolescence, and may provide avenues for other denominations to revitalize their youth programs in a similar fashion. 


\section{CHAPTER 1: THEOLOGY AND HISTORY OF THE CHARISMATIC MOVEMENT THE SCRIPTURAL BACKGROUND OF THE PENTECOST AND CHARISMATA}

The Pentecost, as described in the second chapter of Acts, occupies an important place on the list of formative events in the Christian bible. The book of Acts begins with the end of the life of Jesus of Nazareth, and showcases the early followers of Jesus. According to Ira Jay Martin's biblical interpretation, the church began with a mere two hundred followers, including the twelve disciples, and the day of Pentecost served as an opportunity for an explosion of growth. The scriptural account also includes an occurrence of glossolalia, or speaking in tongues, and has since been connected with being possessed by the Holy Spirit. Throughout the New Testament Paul categorized the glossolalia that occurred at the Pentecost as charismata, or gifts of grace. ${ }^{1}$ According to scripture, the baptism of the Holy Spirit was an important expression of faith for the early Christians, and allowed them to make a strong mark on the world they inhabited. ${ }^{2}$ The appearance of the charismata of the Holy Spirit became the foundational experience for Pentecostal and charismatic movements within Christianity, and is symbolically present within organizations such as Youth Conference Ministries (YCM).

The most written about event at the Pentecost was the receiving of the gift of the Holy Spirit, and the gift truly shifted the religious landscape of its time. Therefore, the first section of this chapter explores the theological implications of the Pentecost. It also

\footnotetext{
${ }^{1}$ Ira Jay Martin, "Glossolalia in the Apostolic Church" Journal of Biblical Literature 63 (1944): 129.

${ }^{2}$ Martin, "Glossolalia in the Apostolic Church" 123-124.
} 
provides the theological context for the allegorical connection to prophetic events in the Hebrew Bible. Finally it showcases how these early Christians utilized charismata.

\section{THE BIBLICAL IMPORTANCE OF THE DAY OF PENTECOST}

An understanding of the Pentecost must begin with the statements that Jesus of Nazareth made to his disciples before he was arrested, tried, and ultimately crucified. In what became known as the Upper Room discourse, Jesus proclaimed that after his death God would instill the spirit from Heaven upon the earth. In a common theological view, the Holy Spirit would take up residence within a new people of God. ${ }^{3}$ In the gospels Jesus says that although he himself would die, God would send forth a "comforter" that would abide with his followers forever. In John 16:7-8 this comforter is explicitly called the spirit of truth, and is said to be coming soon as a guide for humankind and one that will cleanse humankind of its $\sin .{ }^{4}$ The Upper Room discourse theologically forecasted an event in the near future that would bring forth the Spirit of God into the world in which Jesus no longer resided. When evaluating the actions on the day of Pentecost, as presented in the book of Acts, it can be assumed that the followers of Jesus were expecting this event.

Fifty days after Jesus of Nazareth was crucified, Acts states that the festival of the Pentecost began in the city of Jerusalem. According to Joseph A. Fitzmeyer the festival of Pentecost had originally been harvest-related, and named the Feast of Weeks. Greek-

\footnotetext{
${ }^{3}$ Merrill F. Unger, “The Significance of Pentecost” Bibliotheca Sacra 122 (1965): 169.

${ }^{4}$ Unger, "The Significance of Pentecost" 170.
} 
speaking Jews referred to the Feast of Weeks as Pentecost, or the fiftieth day. ${ }^{5}$ However, the importance of the Pentecost had increased thanks to its attachment to the anniversary of Moses receiving the Law at Mount Sinai. According to Clyde Votaw, the festival also occurred during a more favorable time of year in terms of weather than Passover. The favorable climate allowed for it to become a time when a great multitude of worshippers made pilgrimage to Jerusalem. Acts says that the closest followers of Jesus, many of who believed that their leader had ascended to heaven only ten days before, were included in this multitude. According to Acts 1:15, at this time the followers of Christ were limited to only a few hundred in number. Making them a Jewish minority among those in Jerusalem at the time. ${ }^{6}$

According to Bert. B. Dominy, what occurred next at the Festival of Pentecost comprises the scriptural birth story of the Christian Church. The event in Acts 2:4 served the theological purpose of showing that the followers of Jesus were the new people of God. ${ }^{7}$ According to Acts, early on the morning of the fiftieth day after Jesus had been crucified, the select followers of Jesus had assembled for worship and fellowship. At that moment they did not have knowledge of what was about to occur. Acts 2:2-4 states that the house they resided in was filled with the sound of a great wind. Next, fiery tongues descended upon them, and all who inhabited the house were filled with the Holy Spirit. The infilling of the Holy Spirit was followed by the followers of Jesus speaking in

\footnotetext{
${ }^{5}$ Joseph A. Fitzmeyer, "The Ascension of Christ and Pentecost" Theological Studies 45 (1984): 430.

${ }^{6}$ Clyde W. Votaw, “The Great Day of Pentecost” The Biblical World 19 (1902): 47.

${ }^{7}$ Bert B. Dominy, "Spirit, Church, and Mission : Theological Implication of Pentecost" Southwestern Journal of Theology 2 (1993): 34.
} 
foreign tongues. Acts states that the Pentecostal event consisted of the actual infilling of the Holy Spirit into the world. ${ }^{8}$

According to Votaw, the Festival of Pentecost written of in Acts occurred during the Jewish Diaspora, or the dispersion of the Jews to lands far from Judea. According to scripture, when these individuals heard the great noise that accompanied the indwelling of the Holy Spirit into the house of the Christians, they hurried to the house to see what was the matter. Once they arrived at the house the scriptures report that their wondering eyes saw the followers of Jesus expressing themselves by ecstatically yet incoherently speaking in tongues. ${ }^{9}$ The multitude of pilgrims sought an explanation of what they had seen, as their initial belief was that those filled with the spirit had simply drunk too much wine. $^{10}$

The next account in Acts is known as the first sermon of the Christian Church, and it served as Peter's theological explanation of what had just occurred. After the crowd had arrived at the house of the followers of Jesus, Peter stood up before the crowd. It was the words of Peter that served as the most essential element of the early Christian Pentecost experience. The scriptures state that Peter served as the representative of the spirit-filled Galileans who were making their presence known to those who had made pilgrimage from various points of the Jewish Diaspora. In Acts 2:36 Peter proclaims to the entire house of Israel that God had made the Jesus they crucified both Lord and Messiah, and that he had been raised from the dead. Peter then clarified that their ecstatic

\footnotetext{
${ }^{8}$ Fitzmeyer, "The Ascension of Christ and Pentecost" 426.

${ }^{9}$ Votaw, "The Great Day of Pentecost" 48.

${ }^{10}$ Dominy, "Spirit, Church, and Mission : Theological Implication of Pentecost" 37.
} 
speech was not the product of drunkenness, but the signifying mark that they were the witnesses of Christ's resurrection. According to Dominy, the scriptural account states that these followers of Jesus were the new representatives of God on earth. ${ }^{11}$

While it was initially the Galilean followers of Jesus that received the gift of the Holy Spirit at the Pentecost in Acts, these scriptures also show through Peter's first sermon that these gifts were for all individuals who believed in the resurrection. The account shows Peter urging the Jewish people visiting Jerusalem to ask forgiveness for the crucifixion of Jesus, in order that they could also take part in the baptism of the Holy Spirit. ${ }^{12}$ The account also includes Peter beginning his sermon by quoting Joel 2:28-32 speaking of the outpouring of God's spirit inaugurating the Kingdom of God for the people of Israel. According to Merrill F. Unger, the theological goal of mentioning this scriptural prophesy was to illustrate to the Jewish audience at the Pentecost how the baptism of the Holy Spirit was a fulfillment of what was written within Jewish prophetic texts. $^{13}$

\section{PENTECOST: THE BRINGING OF THE UNIVERSAL, PERSONAL, AND}

\section{OVERARCHING CHRISTIAN AGE}

One of the images brought forth through the scriptural account of the Pentecost was that of the followers of Jesus speaking in different tongues to all who were watching in Jerusalem. The mention of foreign tongues showed how universal this new Christian

\footnotetext{
${ }^{11}$ Dominy, "Spirit, Church, and Mission : Theological Implication of Pentecost" 426.

${ }^{12}$ Unger, "The Significance of Pentecost" 171.

${ }^{13}$ Unger, "The Significance of Pentecost" 176-177.
} 
age was meant to become. According to Dominy, the event can also be viewed as a divine reversal of the Tower of Babel account in Genesis 11:1-8. The Babel account tells of humanity being united after the Great Flood, and working to build a tower that would reach Heaven. However according to Genesis, God chose to confound the speech of the united group. The Babel account led to a scattering of peoples throughout the world. According to the account in Genesis, God knew humankind at that time would become too powerful if they were completely united. The account can be contrasted with the Pentecost, where Luke shows that the followers of Jesus came together with devout intensions of honoring their God. Although the authors of both accounts utilize the confounding of tongues, Luke utilizes the Pentecost in order to signify the unity of those who believed Jesus was the Christ. ${ }^{14}$

In contrast to the Babel account in Genesis, the goal of the Pentecostal account in Acts was to commence a perpetual uniting of the people of the world through the Holy Spirit. Also the unifying does not subside in Acts 2. According to Unger the Holy Spirit was offered to the Samaritans in Acts 8, and also to the pure Gentiles in Acts $10 .{ }^{15}$ Unger referred to the gift of the Holy Spirit as a brilliant and pyrotechnic display of languages, one that was utilized in the New Testament to show the growth of the neophyte Christian Church.

Although the indwelling of the Holy Spirit within the early Christian Church is by no means a Lucan invention, Joseph A. Fitzmeyer states that it is only the synoptic author who connected the spirit to the Jewish Feast of Weeks. By associating the Holy Spirit

\footnotetext{
${ }^{14}$ Dominy, "Spirit, Church, and Mission : Theological Implication of Pentecost" 38.

${ }^{15}$ Unger, "The Significance of Pentecost" 175.
} 
with a harvest festival, more specifically one for the season's first fruits, Luke allows his audience to visualize the new multitude of followers as the first fruits of the Christian age. $^{16}$

The Pentecost at the Feast of Weeks was the event that set the stage for the early Christian Church. Scholars have also stressed that this scriptural event would not be recurring throughout the years, unlike the annual Feast of Weeks. Luke's ability to connect this event to both the receiving of the Law of Moses and the Davidic promise of the Kingdom showed the permanence of the first baptism of the Holy Spirit. The account was meant to describe a theologically overarching occasion that would forever vitalize the church. Unger states that the outpouring of the Holy Spirit occurred at the specific time and place it did in order to mark the beginning of the new Christian order. ${ }^{17}$ Just as the Law of Moses presented in the Hebrew Bible cemented God's covenant with the people of Israel, this outpouring of the Holy Spirit in Acts showcased God's continual presence within Christianity. The Pentecost was a unique and unifying event for the early Christian Church, and these early followers of Christ were meant to perpetuate this first Pentecost rather than repeatedly commence it. ${ }^{18}$

\footnotetext{
${ }^{16}$ Fitzmeyer, "The Ascension of Christ and Pentecost" 438.

${ }^{17}$ Unger, "The Significance of Pentecost" 171.

${ }^{18}$ Dominy, "Spirit, Church, and Mission : Theological Implication of Pentecost" 39.
} 


\section{THE PERCEPTION OF GLOSSOLALIA IN THE APOSTOLIC AND POST-}

\section{APOSTOLIC CHURCH}

After the first occurrence of glossolalia at the Pentecost in Jerusalem, the desire for a Holy Spirit Baptism became quite common in the Christian Church. Ira Jay Martin states that as individuals would enter into the Christian fold they sought this form of charismata in order to experience the presence of the spirit in their life. Those individuals who were able to speak in tongues spoke incoherently and ecstatically, however they quickly gained prestige within the religious community. Since this ability signaled a close connection to a divine force, and also with the apostles on the day of Pentecost, it was often taken as a sign that the believer had found favor with the lord. ${ }^{19}$ Those who were able to speak in tongues quickly began to believe that the Holy Spirit elevated them above their fellow man.

While glossolalia did carry with it a certain level of prestige, there was much debate about its use as a form of evangelism. The debate can be seen within the teachings of Peter and Paul in the New Testament. The first occurrence of this phenomenon at the Feast of Weeks certainly drew a crowd, however much of that crowd initially denigrated it as an act of mass public drunkenness. Ira Jay Martin claims that Peter was the true hero of this formative event in the Christian Church, as he was able to stop the event from becoming a religious sideshow. The sermon that Peter delivered on the day of Pentecost in Acts was not delivered in ecstatic tongues, but in Aramaic. Acts 2:41 states that the crowd gathered because of the unintelligible display of language, however those added to the Christian movement that day were added thanks to the intelligible sermon delivered

\footnotetext{
${ }^{19}$ Martin, "Glossolalia in the Apostolic Church" 127.
} 
by Peter. The purpose of Peter's sermon was to the show that although glossolalia had flare, it lacked the evangelical substance of a comprehensible sermon. ${ }^{20}$

Peter was not the only individual in the New Testament who stated that the performative gifts of the spirit lacked the ability to sustain the church. In 1 Corinthians 14:23, Paul said that if an outsider walked into a Christian meeting and witnessed nothing other than speaking in tongues, the one who witnessed the glossolalia would not be able to glean any spiritual growth out of what he had experienced. While Paul believed that glossolalia was impressive in its demonstration of the Holy Spirit, he also said that without further instruction it actually provided little guidance to a follower of Christ. Paul also installed restrictions such as that no more than three glossolalists could speak during one service, that they must speak separately as opposed to in concert, and that there always needed to be an interpreter present when one spoke in tongues. These restrictions showed Paul's reservations about this spiritual gift, and also his desire to keep the focus on a message that could be comprehended by many as opposed to only a few. ${ }^{21}$

Although Peter realized the need for an intelligible sermon along with the charismatic event at the Day of Pentecost, few New Testament authorities did more than Paul to promote the dangers of this ecstatic gift. In Galatians 5:16-26, Paul stated that believers needed to be infused with the spirit and to utilize it in their daily existences. According to Martin, Paul believed that love was the greatest form of charismata. Paul's

\footnotetext{
${ }^{20}$ Martin, "Glossolalia in the Apostolic Church" 128.

${ }^{21}$ Martin, "Glossolalia in the Apostolic Church" 129.
} 
writings in Galatians further evidenced his belief that charismata needed to have direct evangelical purposes. ${ }^{22}$

Paul further distanced the Church from the use of glossolalia by stating that another worthy example of charismata was prophecy. In 1 Corinthians 14:3, Paul said that the prophet had the ability to understand all mysteries and contained great knowledge of the world. According to H.B. Swete, Paul stated in 1 Corinthians 14:3 that the individuals who possessed this form of charismata were able to build up the faithful, strengthen the weak, and comfort the distressed. The ringing endorsement of prophecy is in line with Paul's aversion towards glossolalia, as the former allowed for the building up and education of all individuals within the church. Paul believed that a prophet could educate even church members who did not possess any spiritual gifts; however those members devoid of spiritual gifts would not gain any spiritual insight while observing individuals speaking in tongues. ${ }^{23}$

The writings of Paul provide a foundation for why those of mainline Christian denominations today look askance at the practice of glossolalia. Although glossolalia and other gifts of the spirit carry a negative connotation in the minds of mainline Christianity today, Pentecostal Christian groups still hold elements of charismata in high regard. However, no matter the perception of these charismata, the majority of both of these groups believe that spiritual gifts were filtered out of the church within the first one hundred years of the Common Era. According to Eusebius A. Stephanou, Mainline Christians believed that the gifts were retired after serving their purpose of establishing

\footnotetext{
${ }^{22}$ Martin, "Glossolalia in the Apostolic Church" 130.

${ }^{23}$ H. B. Swete, “The Prophets in the Christian Church" The Biblical World 23 (1905): 205-206.
} 
the church. In contrast, Pentecostal groups believe that the young church quickly lost its way thanks to its abandoning of expressive charismata. ${ }^{24}$ Although these two groups have differing opinions on the actions of the early church, both believe that the use of spiritual gifts quickly lost its place in the Christian Church.

The glossolalia that occurred at the Day of Pentecost can be understood as an occurrence that helped birth the Christian Church within the New Testament. The event allowed for the entering of the Holy Spirit into the profane realm, connected the early Christian Church to important events in the Hebrew Bible, and also showed the unique characteristics of the new Christian age that was beginning. While glossolalia has had ebbs and flows in term of its place within the Christian community, its importance within the scriptures as a formative event in the church remains.

\section{THE MODERN CHARISMATIC MOVEMENT WITHIN CHRISTIANTY}

In the early twentieth century, the use of glossolalia and other ecstatic expressions of worship found rebirth within the Pentecostal movement. According to Randall Balmer, on January 1, 1901, Agnes Ozman, a student at Bethel Bible College, began speaking in tongues. ${ }^{25}$ Other students who witnessed Ozman's ecstatic uttering connected her actions to Pentecost, believing that they were witnessing a sign that charismata had returned to the Christian Church. The significance of this event occurring on the first day of a new century was also not lost upon these students. They understood

\footnotetext{
${ }^{24}$ Eusebius A. Stephanou, "Charismata in the Early Church Fathers" Greek Orthodox Theological Review 21 (1976): 125.

${ }^{25}$ Randall Balmer, and Lauren F. Winner, Protestantism in America, (New York City: Columbia University Press, 2002) 77.
} 
this outpouring of the Holy Spirit to be a revitalization of Christianity, which they believed had become spiritually indifferent. ${ }^{26}$ While these young Pentecostals represented only a small strain of evangelicalism in America, they were a unique group that craved religious emotion and feeling as a way to verify the presence of God in their lives. ${ }^{27}$ The fact that these Pentecostals were a small minority within their religion allows for the metaphorical connection to the followers of Jesus at the Feast of Weeks, allowing for both Pentecostalism and charismatic Christianity to be seen as movements that strived for a connection to the earliest Christians.

Although this first modern Pentecostal event took place in Kansas, it quickly became a national phenomenon. Charles Fox Parham, the founder of Bethel Bible, also claimed to have spoken in tongues. Parham was essential in the spreading of Pentecostalism to Kansas, Missouri, and Texas. While Parham was in Houston his Pentecostal message caught on with a group known as the Evening Light Saints, and more importantly with William J. Seymour. Seymour, who was a hotel waiter, migrated to Los Angeles and began drawing large crowds to his prayer meetings. The crowds grew to such a large number that they had to be moved to a warehouse at 312 Azusa Street. The quickly named Azusa Street Revival marked the first time that the Pentecostal Movement received national attention. The meetings lasted several hours and took place multiple times a day. They were marked by enthusiastic sermons, singing of hymns, and testimonies by those who had received the gift of tongues. Observers of the revival

\footnotetext{
${ }^{26}$ Randall Balmer, Jon Butler, and Grant Wacker, Religion in American Life, (New York City: Oxford University Press, 2003) 313.

${ }^{27}$ Balmer, Butler, and Wacker, Religion in American Life, 314.
} 
quickly began to raise their arms towards heaven, beckoning for the Holy Spirit to baptize them as well. The apocalyptic theme present in Topeka followed the movement to Los Angeles, as the San Francisco Earthquake on April 18, 1906 occurred just a few hundred miles away from the revival. According to Balmer this led many to wonder whether the end of the world was upon them. ${ }^{28}$ The Azusa Street Revival can be seen as a modern parallel to the Lucan Day of Pentecost, as both effectively broadcasted the belief in the baptism of the Holy Spirit to a larger audience.

The doctrines of Pentecostalism can trace their roots to the Holiness movement of the late nineteenth century within Methodism and other mainline Christian denominations that focused on personal piety. However both Pentecostal and Holiness advocates felt increasingly marginalized within their denominations, leading to an exodus and the formation of distinctively Pentecostal Christian Churches. Pentecostalism spread quickly after the Azusa Street Revival, forming denominations such as the Pentecostal Holiness Church, The Church of God in Christ, and the Assemblies of God. The Assemblies of God became the largest Pentecostal denomination in North America.

While Pentecostalism hoped to revitalize Christianity with an infusion of charismatic gifts, its adherents believed that the only way of doing this was to separate from mainline American Christianity. However the same cannot be said of the charismatic movement within Christianity that began in the 1960's. While both charismatics and Pentecostals believed in charismatic Gifts, the former chose to remain within denominations that usually looked askance at the gifts of the Spirit. While Pentecostals believed that glossolalia had to be present in order to have an authentic

\footnotetext{
${ }^{28}$ Balmer, Butler, and Wacker, Religion in American Life, 315.
} 
Christian Church, charismatic Christians placed a far greater emphasis on helping denominational Christianity replicate the apostolic church. While Pentecostals focused on glossolalia, charismatic Christians desired for all Christians to renew their denominations by modeling their ecclesiology after their interpretation of the first century Christian Church.

The charismatic movement, also known as neo-Pentecostalism and charismatic renewal, forged its way into the American religious landscape thanks to an Episcopal priest named Dennis J. Bennett. News began circulating that Bennett had received the baptism of the Holy Spirit and practiced the gift of glossolalia. Over one hundred of his parishioners also spoke in tongues, quickly making them outcasts within their church in Van Nuys, California. Bennett soon left this church and took over a struggling Episcopal parish in Seattle, Washington. The difference between Bennett and Pentecostals such as Seymour is that Bennett chose to remain within a mainline denomination, although that denomination as a whole did not view charismatic gifts in a positive light. ${ }^{29}$ When comparing the charismatic movement to the Apostolic Church or Pentecostalism one sees that each group's ability to practice spiritual gifts was originally met with a great deal of negativity from the larger established religion they were within. However what separates the charismatic movement is that it chose to renew Christianity from within.

It is important to view charismatic Christianity as a renewal movement, meaning that those who champion this cause believe there is a clear need for repair of the Church. Just as Paul stated that the gift of glossolalia had no purpose in the Christian Church if it did not lead to new parishioners, charismatic Christians were more concerned with the

\footnotetext{
${ }^{29}$ Balmer, and Winner, Protestantism in America, 78.
} 
revitalization of the Christian Church than they were of their own personal spiritual renewal. ${ }^{30}$ Generally charismatics remained in their denominations as opposed to starting offshoot churches, although there was still an inherent contradiction at hand within neoPentecostalism. According to Scott. H. Hendrix, the desire for charismatic Christians to replicate the apostolic Christian Church also implies that the current ecclesiology of mainline Christianity lacks legitimacy. ${ }^{31}$ When charismatic Christians advocate for increased attention to the baptism of the Holy Spirit they are also accusing the modern Christian church of losing touch with the Holy Spirit that descended on the day of Pentecost.

While supporters of charismatic Christianity claim that they are only attempting to bring greater awareness of the Holy Spirit to their denominations, one can understand why non-charismatics within their denominations have viewed them negatively. While minority movements within Christian Churches, such as monasticism and pietism, have been able to revitalize and find comfortable niches within mainline Christianity, charismatic movements are walking a tightrope that could lead to their eventual renunciation of mainline Christianity. Hendrix states that this movement may only be old wine in new skins, meaning that charismatics are not actually any different from Pentecostals who were rejected and eventually left mainline Christianity. ${ }^{32}$ However, it is important to note that charismatic movements are present within most Christian denominations today.

\footnotetext{
${ }^{30}$ Scott H. Hendrix, "Charismatic renewal: old wine in new skins," Currents In Theology And Mission 4 (1977): 164.

${ }^{31}$ Hendrix, "Charismatic renewal: old wine in new skins," 165.

${ }^{32}$ Hendrix, "Charismatic renewal: old wine in new skins," 166.
} 
What truly makes charismatic renewal new wine is that it does not place glossolalia at the center of its ecclesiology. The importance of this movement is not in the speaking of tongues, but instead in the realization of the fullness of the Holy Spirit within the Christian Church. Charismatics believe that the power of the Holy Spirit will result in the exercise of spiritual gifts. While this may include glossolalia, spirit healing, and spirit baptism it must include an enthusiasm and passion brought forward through the understanding that the Holy Spirit is alive within the modern Christian Church. ${ }^{33}$

\section{THE THEOLOGY AND PRACTICES OF THE CHARISMATIC MOVEMENT}

According to Frederick Sontag, in order to be a charismatic one must simply have a strong response to the Holy Spirit. ${ }^{34}$ In order to understand charismatic theology one must realize that the power of the Holy Spirit comes not from its initial presence, but from the individual's enthusiastic response to it. A charismatic theology must focus not only on the Pentecostal event that brought forth the inspirational engine of the Holy Spirit, but also on the ascension of Christ that occurred fifty days before. The ascension also led to the absence of a direct divine form of leadership for the church. According to Sontag this leadership was later provided by the infilling of the Holy Spirit within the Church, and the gifts provided by the spirit connect charismatic Christians to their divine source of inspiration. These actions may consist of glossolalia, but it is not essential to charismatics. A charismatic theology states that in order for the actions of the church to

\footnotetext{
${ }^{33}$ James H. Smylie, "Testing the spirits in the American context : great awakenings, pentecostalism, and the charismatic movement," Interpretations 33 (2008): 40.

${ }^{34}$ Frederick E. Sontag, "Should theology today be charismatic," Journal Of The Evangelical Theological Society 30 (1987): 199.
} 
have a divine inspiration, they must remain present to the fact that the spirit of God has replaced Jesus of Nazareth as the pure metaphysical leadership in the profane plan. ${ }^{35}$ In order for the church to trust its profane actions, it must remain constantly attached to the energy source that is the Holy Spirit.

The focus upon the energy source once again places great importance on the charismatic's desire to replicate the methods of the first century church, which was the first to receive the baptism of the Holy Spirit. The focus does not necessarily release the charismatic Christian from the performance of the established religious rituals within their denominations; instead it forces them to perpetually focus their attention on the presence of the Holy Spirit. In all religious action the emotion brought forth by the Holy Spirit must remain present, or the parishioner is at risk of missing out on the dynamics of this spirit. ${ }^{36}$ According to Ronald Knox charismatic individuals are often denounced as innovators, and in many ways they are in relation to the status quo. However, they believe that their Holy Spirit-inspired actions are necessary in order to connect presentday Christianity to the practices of the first followers of Jesus of Nazareth. ${ }^{37}$

Underlying the crowning spiritual practice of glossolalia is the confession of faith that Jesus Christ is Lord, and the desire to utilize that confession to show love for one's fellow man. According to charismatic Christians, the descended Holy Spirit was not meant to be evidenced only through a replication of the original Pentecostal event, but instead it was to be evidenced by the transformed lives of the followers of Jesus. John

\footnotetext{
${ }^{35}$ Sontag, "Should theology today be charismatic," 200.

${ }^{36}$ Sontag, "Should theology today be charismatic," 201.

${ }^{37}$ Sontag, "Should theology today be charismatic," 202.
} 
Painter says the original use of glossolalia in Acts did not consist of ecstatic unintelligible speech, but instead it was the first reference that the Apostles' religion was one for all to hear and understand. The first reference can be differentiated from the glossolalia referred to by Paul in 1 Corinthians that consisted of little more than a religious performance, selfishly showcasing the personal piety of a select few. While the former in Acts had a distinct evangelical goal, the latter in Corinthians served little purpose in the matter of church growth. The theology of the charismatic movement is one of enthusiasm and inspiration brought forward by the Holy Spirit; however these gifts must be put into action in order to transform the Christian community and revitalize the church as a whole. ${ }^{38}$

\section{PRACTICING THE THEOLOGY OF THE CHARISMATIC MOVEMENT}

The early Christian, Pentecostal, and charismatic movements all had humble beginnings. Each started as a small minority within its respective religious community. However today Pentecostals and charismatic Christians comprise over fifty million parishioners worldwide. ${ }^{39}$ According to Karla Poewe these groups, especially the charismatic Christians, have ceased their tendency to be composed of the marginal within society. The ability of the charismatic movements to remain within their denominations has enabled their demographics to include the urban middle class. The insider perspective of the charismatic movement finds influence in far more than the first-century Christian

\footnotetext{
${ }^{38}$ John Painter, "The charismatic movement and the New Testament," Journal Of Theology For Southern Africa 7 (1974): 60.

${ }^{39}$ Karla O. Poewe, "The Charismatic Movement and Augustine: The Challenge of Symbolic Thought in the Modern World," Pneuma 11 (1989): 23.
} 
church, and Poewe states that St. Augustine of Hippo was a key contributor to their method of religious practice.

One of the key teaching mechanisms for the charismatic movement is the testimony. The testimony consists of a member of the congregation telling the story of his or her individual walk with God. According to Poewe this testimony is distinctly Augustinian, as it utilizes many elements from his Confessions. The first of these elements lies in the conversion process and the conversion drama. The conversion process is the overall story of one's entrance into the Christian fold, meaning the testifier will trace his or her growth throughout the process. Any distinct personality or lifestyle changes brought forth through this conversion will be present in the conversion process. On the other hand the conversion drama is the charismatic portion of the testimony. The drama consists of the heightened state of awareness that took place when the Holy Spirit overtook the individual. ${ }^{40}$ The interplay of these two portions of the testimony show the importance of what comes after the initial indwelling of the Holy Spirit. Becoming a new creation after the conversion drama is the inspiring force that leads the charismatic to keep the Holy Spirit as the central element of spiritual existence, as the existence lived before the indwelling is now viewed as undesirable. ${ }^{41}$

Another Augustinian method at work in the charismatic movement is found through the use of metonymy. The idea is described as having one symbol automatically trigger the memory of another. Within charismatic Christianity the triggering symbol is

\footnotetext{
${ }^{40}$ Poewe, "The Charismatic Movement and Augustine: The Challenge of Symbolic Thought in the Modern World," 24.

${ }^{41}$ Poewe, "The Charismatic Movement and Augustine: The Challenge of Symbolic Thought in the Modern World," 25.
} 
the initial conversion drama, and the emotional event is used as the signifier for the charismatic Christian's religious beliefs. The peak experience of conversion for the charismatic Christian consists of their emotional response to the Holy Spirit, and any elements of charismata that may follow. When Augustine described his conversion process all the details preceding the conversion drama were seen as signposts leading towards this emotional event, and the details after the drama can be seen as a direct result of his dramatic conversion. ${ }^{42}$ In both Augustine's and the charismatic Christian's testimony the conversion drama is not only a metaphor for their spiritual existence, it is the central element that encapsulates and defines their religious identity. Charismatic Christians will understand scripture, religious fellowship, and devotion as important metaphors for their lives as Christians. However, they view their initial conversion drama as the deepest connection they have experienced. The importance of this experience and emotion in the lives of these charismatic believers cannot be understated, as this first experience with the Holy Spirit is what provides their spiritual motivation.

While this initial importance of the experiential and emotional provides the charismatic with the catalytic event, intellectual forces also play a very important role in the conversion drama. One must remember that after the apostles initially received the Holy Spirit, Peter quickly gave a wholly intelligible sermon. After the initial euphoria of his conversion drama, Augustine wrote of a great intellectual desire to read, comprehend, and gain a greater awareness of the religious gifts that had been bestowed upon him. ${ }^{43}$ In

\footnotetext{
${ }^{42}$ Poewe, "The Charismatic Movement and Augustine: The Challenge of Symbolic Thought in the Modern World," 26.

${ }^{43}$ Poewe, "The Charismatic Movement and Augustine: The Challenge of Symbolic Thought in the Modern World," 27.
} 
the realm of charismatic Christians this intellectual curiosity consists of understanding how to cultivate the spiritual gifts in their lives in order to revitalize their Christian faith. Just as Paul instructed the Corinthians to emphasize the spiritual gifts that were successful in order to evangelize, charismatic Christians utilize personal testimonies in order to instruct future generations of their faith on how to experience their own conversion dramas. If the charismatics only focused on the experiential phenomena, they would not be able to guide others within their fold on how to identify their own metonymic event.

The religious practices of the charismatic movement are greatly interpersonal, as parishioners are encouraged to learn from each other in a very utopian environment. Whether or not the parishioner has experienced a conversion drama, it is understood that they have started their conversion process. No matter what phase of the process the individual is in, they are encouraged to listen to the testimonies of the other members of the community. These Augustinian confessions are understood to be overflowing with metonymic signs, and by seeking to comprehend these signs the neophyte member of the movement can better understand similar signs within their own lives. Members of the movement that have already experienced their conversion dramas are also encouraged to listen to testimonies. By recounting their own conversions, and also intellectually digesting the testimonies of others, they are better able to remain focused on their charismatic motivation force. ${ }^{44}$

\footnotetext{
${ }^{44}$ Poewe, "The Charismatic Movement and Augustine: The Challenge of Symbolic Thought in the Modern World," 30-32.
} 


\section{ISSUES FOR THE FUTURE OF THE CHARISMATIC MOVEMENT}

The charismatic movement within Christianity has lofty aspirations of revitalizing the church as a whole through the inspiration of the Holy Spirit. Instead of leaving the mainline denominations behind, they instead choose to reinvigorate from within. When predicting the future of this movement Martyn Percy recalls two parables from Matthew that have prophetic implications for the future of charismatic Christianity. Matthew 5:14 showcases Jesus claiming that the Christian community should be like a city on a hill. The community should remain visible and progressive for the rest of the world to see. Matthew 7:24 then presents Jesus claiming that a strong religious life must have a rocklike foundation, as opposed to one built on sand. These two parables present an interesting situation. Christianity is directed to continue to be visible to the different communities and generations, while at the same time always have a firm foundation upon which to endure the waves of societal change. While scripture, liturgy, and other established rituals provide the foundation for the mainline denominations; Percy wonders if those of the charismatic persuasion have enough stability in order to endure the waves of change. Percy even goes on to describe the charismatic movement as a city on a beach, forecasting that this group's experience-centered foundation will not be able to weather future struggles. ${ }^{45}$

Percy's accusations of instability are not without support, as the charismatic movement has shifted its shapes and forms a great deal in only fifty years of existence. Charismatic Christians have often welcomed waves of the Holy Spirit that served as

\footnotetext{
${ }^{45}$ Malcolm Hamilton, Stephen Hunt, and Tony Walker, Charismatic Christianity: Sociological Perspectives, (New York City: St. Martin's Press Inc., 1997) 206.
} 
catalytic forces for their movement. Whether these waves are health-and-wealth movements, shepherding movements, house churches, or charismatic leaders in the mold of televangelists, each has had both positive and negative effects on the religion. While these catalysts have perpetually refreshed the movement with their arrival, each has also brought with it schism and erosion of membership. The highly individualized nature of the inspiration of the Holy Spirit allows for innovation and personal growth, but it does not always lead to a mandate of agreement. The firm foundation of canonized scriptures, liturgy, and rituals does not lead as easily to renewal, however it provides a great deal more stability for the faithful. Those of the charismatic persuasion are not offered this security according to Percy; instead they must hope that the next wave will provide enough revitalization in order to weather any ecclesiastical erosion in the congregation. ${ }^{46}$

YCM can be described as a new wave of charismata within the Presbyterian Church. This group looks to revitalize the local churches through encouraging the youth to have an enthusiastic response to the Holy Spirit. However in order to revitalize these churches YCM must be able to peacefully cooperate with denominations that have not always looked at charismata with acceptance.

Other issues at hand within the charismatic movement are the consequences of the routinization, as opposed to revolution, of charisma. Although charismatic Christianity has found a niche within almost every mainline denomination, its presence has not served to revolutionize its host body. According to Nigel Scotland by the time a charismatic movement has matured enough to sit at the moving and shaking table within a church body, it has likely lost the edge it originally needed to revolutionize. The use of

\footnotetext{
${ }^{46}$ Hamilton, Hunt, and Walker, Charismatic Christianity: Sociological Perspectives, 207-208.
} 
metonymy and testimony are effective in order to help mature young charismatic's knowledge of the movement. However, in order to cause real change within the denomination, organization is needed. However the cultivation of organization also leads to the loss of the cutting edge that birthed the original desire for change. ${ }^{47}$ By defining and routinizing the charismatic phenomena these parishioners risk killing the true life of the spirit, causing them to lose their revolutionary identity within the larger church body. Just as charismatics must rely on continual waves of renewal in order to keep their religion fresh, they must also be aware that each wave leads them closer to routinization. The charismatic movement within Christianity has found its niche within its host religion. However only time will tell if it is able to truly revolutionize the mainline denominations of American Christianity.

\footnotetext{
${ }^{47}$ Hamilton, Hunt, and Walker, Charismatic Christianity: Sociological Perspectives, 214-215.
} 


\section{CHAPTER TWO: CASE STUDY ON THE GREAT ESCAPE}

\section{A HISTORY OF YOUTH CONFERENCE MINISTRIES}

One of the main differences between Pentecostal and charismatic movements within Christianity is that the latter places great importance on remaining within a mainline Christian denomination. While both movements place importance on the centrality of the power of the Holy Spirit to their movement, since the 1960s charismatic Christians have worked to instill this power into nearly every Christian denomination. YCM is an example of a charismatic movement within the Presbyterian Church in America, and it effectively showcases how a Holy Spirit centered message attempts to coexist with mainline Christianity. The present chapter will focus mainly on The Great Escape, YCM's youth retreat for middle school students.

Youth Conference Ministries was originally known as PFR Youth, and served as the center for youth ministry within Presbyterians for Renewal. Presbyterians for Renewal began at a conference of over seventy ministers and elders of the Presbyterian Church (U.S.A) that were specifically interested in renewing the church by returning to the original roots of the Christian Church. When this original conference concluded, those attending signed a covenant of renewal that presented the goals of this organization. These goals consisted of a deep commitment to Jesus Christ as the savior and redeemer of the world, an understanding of the scriptures as a source of pure authority, a desire to lead a holy life, and finally a call to repentance on the basis of one's personal faith in 
Christ. ${ }^{48}$ The latter two goals showcased by PFR bring to light its charismatic influences. PFR was an organization that believed the Presbyterian Church had lost its ability to harness the strength of the Holy Spirit, and that only through charismatic renewal could the church reignite the desire to revolutionize its denomination. While PFR was formed as a separate entity from the Presbyterian Church, it was birthed in order to be a renewalcentered resource for it.

Although PFR Youth officially began in 1988, the individuals behind the organization had been putting together youth retreats since the late seventies. They originally launched Fun in the Sun, which served as a retreat for high school students. The retreat originally only served 300 students and had one location in Jekyll Island, Georgia; however it has since grown to serve over 4,000 students on an annual basis. The organizers of Fun in the Sun also created Son Servants in 1982, which is a mainline denominational short-term missions program. Today Son Servants consists of over twenty mission sites, and sends out over 1,500 student mission workers annually. Finally in 1984 the organizers of these two previous retreats created the Great Escape, and it was created in order to provide high quality ministry opportunities in the mold of Fun in the Sun. When the first retreat commenced on the campus of Kings College in Bristol Tennessee, it was the first national middle school religious conference of its kind. It has since grown to serve over 5,000 middle school students annually and regional sites for

48 “History," Presbyterians For Renewal, accessed February 3, 2013. 
the Great Escape can be found in Tennessee, Colorado, Pennsylvania, Wisconsin, North Carolina, Mississippi, and Florida. ${ }^{49}$

After gaining an understanding of the types of retreats these organizers were able to put into action, one sees that even before becoming a part of Presbyterians for Renewal the group of organizers had great potential for growth. In 1989 the organization officially became PFR Youth, and served as the youth ministry outlet for PFR. It was greatly thanks to the partnership with PFR that these three retreats have reached their current size and influence. However in the spring of 2003 the growth of PFR Youth led its leadership to believe that it could be more effective as its own independent organization. The desire to become independent led to the creation of Youth Conference Ministries (YCM), an organization that would have its own Board of Directors and CEO. Many of the Board of Directors, including the CEO were part of the original organizers of the first Great Escape. Although YCM officially separated from Presbyterians for Renewal it has maintained PFR's desire to remain ardently attached to helping students cultivate a personal relationship with Jesus Christ through the power of the Holy Spirit. There are also multiple PFR representatives on the YCM Board of Directors, allowing for this independent organization to remain faithful to its Presbyterian roots. While the independent nature of YCM appears to shift it towards being a Pentecostal organization, it is important to remember that YCM's goal has always been to faithfully serve the youth of the Presbyterian Church of America. The main ways YCM works to serve the Presbyterian Church of America is through creating students who are charismatically

49 “Our Mission and Vision,” Youth Conference Ministries, accessed February 3, 2013. 
inspired to serve their local church and leadership that will serve as the future leadership of the Presbyterian Church.

\section{AN ETHNOGRAPHY OF THE GREAT ESCAPE}

Chapter 2 focuses specifically on the Great Escape Southwind, which holds two separate five-day retreats in the summer months. The retreat is located in Ocklawaha, Florida and takes place from late July to early August. The Southwind site sits upon Long Lake just on the edge of the Ocala National Forest, allowing for this specific Great Escape to have an isolated and peaceful environment to showcase its message. Since 2000 the specific retreat has averaged over 478 students per summer and also served ninety-four churches. The majority of these are southern Presbyterian Churches. In terms of demographics, the students who attend The Great Escape Southwind are middle class Caucasian students. In fact many churches that have stopped sending students to the Great Escape chose to do so based on demographic reasons. One youth pastor from Miami Springs stated that his desire to reach out to Hispanic students who live in less affluent neighborhoods simply did not fit with the overall student population that attends the Great Escape Southwind each summer. Despite these demographic discrepancies church attendance numbers have remained constant throughout Southwind's existence as a Great Escape site.

Although the setting of the retreat is isolated, there are plenty of activities that are utilized in order to keep these adolescent students enthusiastic throughout the week. When arriving at the site one's eyes are quickly drawn to the sandlot inspired baseball field, beach volleyball courts, and extensive water park that includes the exhilarating 
Hurricane water slide. However these worldly activities are only the appetizers provided by camp directors, as the students are quickly made aware of the truly important mission to which they are about to partake. While the retreat organizers are interested in providing a fun environment for their students, the center of each activity is focused on introducing the students to Jesus Christ in order for them to accept the power of the Holy Spirit into their lives.

The two types of religiously centered activities at the Great Escape consist of large inclusive meetings and smaller local church specific meetings. The larger meetings are composed of the afternoon and evening programs. In these programs the students are spiritually enriched and entertained by speakers, musicians, skits, and other group activities. It is in these larger meetings that the message of the Great Escape is presented to the students. These larger meetings are then complemented by smaller church specific activities that help the students digest the message in a more intimate setting. The first of these activities consists of the daily morning quiet time. Quiet time is reserved for helping the young students learn how to have effective alone time reflecting on the message of the Great Escape. Students are provided with a resource booklet that aids them in their scripture reflection, calling for them to create a journal that will show their spiritual growth throughout the week. The private devotional time will prove to be a useful skill in the spiritual lives of these students after they leave the Great Escape.

The second smaller activity consists of daily small group meetings that follow the afternoon program. These small groups are usually gender specific, affording these neophyte Christians an opportunity to share their feelings and opinions of the afternoon speaker's message with their fellow students. The final church specific activity are 
known as Bed Time Talks (BTTs) and these serve as the main reflection period that follows the evening program. Instead of small, gender specific groups, BTTs are meetings for each local church. At BTTs the leaders will give their testimonies throughout the week, while at the same time encouraging their students to share how they have been interacting with the power of the Holy Spirit throughout the week. Both small groups and BTTs provide the local churches with the opportunity to shepherd the students along in their journey with the Holy Spirit.

There is also a daily leader meeting reserved specifically for the planning team and the local church leaders. The leader meeting allows for the retreat director, speakers, and musicians to inform each local church about the religious material they will be utilizing to reach their students. By making the local church leadership aware of what will be presented, they are better able to respond to the questions and issues that their students will be responding to throughout the five-day retreat. It also gives all leadership a chance to be free of their students, have a cup of coffee, and regain the necessary energy needed to shepherd the students along in their journey with the Holy Spirit.

The two major weeklong activities at the Great Escape are the afternoon and evening programs. These activities take place at the Marina, a conference center with a prominent stage. Each specific Great Escape has two different speakers for each respective program. At the Great Escape Southwind in 2012 the afternoon speaker was a white female while the evening speaker was white male. The goal for these programs is to provide the students with an opportunity to gain a deeper understanding of the Christian message, in hopes that the students will have a charismatic experience with the Holy Spirit. Each speaker introduces scriptures that showcase both the power of God and 
the divine compassionate act of sacrifice of Jesus on the Cross. These scriptures are intertwined with the personal testimonies from each speaker, giving the students an example of a charismatic conversion upon which to model their own.

\section{THE CHARISMATIC TESTIMONY AT THE GREAT ESCAPE}

In the charismatic movement one of the main tools utilized in order to experience the Holy Spirit is the testimony. The testimony consists of an individual recounting his or her conversion process and conversion drama. At the Great Escape Southwind 2012 the evening speaker utilized his own testimony in order to reach the students. The speaker began his conversion process by showing how he had not always placed the Holy Spirit at the center of his life. While this speaker had been a Christian throughout his entire life, he made it known that he had not actually experienced the Holy Spirit until he was in college. After receiving a soccer scholarship, the speaker stated that his athletic aspirations had taken a more prominent position than his spiritual aspirations. However at the beginning of his college career the speaker shattered his ankle on the pitch, negating any future as an athlete. The speaker had always craved complete control of his life, and it was not until it had been seized from him that he actually was able to experience the power of the Holy Spirit. After his career as an athlete ended prematurely, the speaker sought refuge within the Christian communities at his college. It was through this new close connection with Christianity that he was able to experience the Holy Spirit, and discovered that his charismatic gift would be in the field of youth ministry.

The specific testimony of the evening speaker perfectly characterizes those of the charismatic movement and of the Great Escape. The speaker tells of his existence before 
he was filled with the Holy Spirit, and of the now undesirable goals that filled his mind. These goals are presented as worldly and unfulfilling, and happiness and fulfillment are not found until one surrenders their life to the Holy Spirit. While this type of charismatic conversion does not consist of glossolalia, it places an enthusiastic response to the Holy Spirit at its core. The speakers and other leadership at the Great Escape proclaim that true peace cannot be found until one surrenders to the Holy Spirit, with the surrender composing the beginning of the conversion drama. The testimony is especially effective when speaking to the adolescent students, many of whom are struggling with their lives outside of the church. Some students are struggling with parental relations, bullying at school, or a litany of other adolescent issues. When presented with a message of a more desirable existence with the Holy Spirit, the students are easily motivated to experience the filling of the Holy Spirit in their lives. The idea of a more desirable existence can be seen as the Holy Spirit providing a crutch for the more difficult portions of adolescent life. While certain students who attend the Great Escape are confident young men and women, others are greatly in need of support as they enter into their formative teenage years. Providing the power of the Holy Spirit reinforces the confident mindsets of those students whose teenage years are going well, and also provides an important resource towards those who are very much looking for their place in the world.

It is also important to state that the organizers of the Great Escape also place a day of Pentecost form of activity at the center of each retreat. The Great Escape's Pentecost is centered on the third evening program that also showcases the speaker's conversion drama. After the speaker dramatically states his case about the power of the Holy Spirit, the students are sent out of the Marina in order to reflect on the message they have just 
heard. Since the students have been hearing about the power of the Holy Spirit throughout the week from the Great Escape leaders and their local church leaders, a great number of the students will choose to accept the Holy Spirit on this evening. The placing of this conversion night on the third day of the retreat also gives leadership two more days in order to instruct these new charismatic Christians in how to properly and enthusiastically respond to the Holy Spirit.

Without the use of testimony, the speakers would not able to properly relate to the spiritually seeking students who attend the Great Escape. However thanks to their ability to reach the students through their own conversion process and conversion drama, the students are able to locate where they are on their own spiritual journey. The relatable charismatic message provides the students with an ideal model upon which to mold their spiritual journeys. It is also a message that can be utilized by the local church leadership in the smaller church specific meetings. The message shows the students that while they may be at a different stage in their spiritual journey, they can view the leadership at the retreat as a needed role model in order to experience their own charismatic conversion.

\section{SYMBIOTIC LEADERSHIP AT THE GREAT ESCAPE}

The leadership of the Great Escape consists of the adult planning team, a high school and college aged work crew, and also a summer staff that mainly works behind the scenes. Many of these individuals have either been involved with planning the Great Escape since its conception or actually attended the Great Escape as students themselves. Great Escape leadership provides the students with many different role models to learn from while they are at this five-day retreat. These role models are essential to the Great 
Escape, as one of the main goals of YCM is to educate future generations of the Presbyterian Church. The leadership has already experienced the charismatic Holy Spirit in their personal relationship with the divine, quite possibly at the Great Escape or another YCM retreat, and this motivates them to help each student respond enthusiastically to the spirit while they are at the Great Escape. If successful they provide an important service to the Presbyterian Church of America, in that they aid the local churches in keeping their adolescent members involved before they reach adulthood. Throughout their time at the retreat the students are being educated about the power of the charismatic Holy Spirit, and the leadership hopes that this will keep these students plugged into the Presbyterian Church as they enter the post-teenage stages of their lives.

While the leadership of the Great Escape hopes to provide an opportunity for substantial spiritual growth during the five-day retreat, this organization is then faced with the issue of the amount of time they have with the students. Even if they are able to instill these students with the Holy Spirit while they are at the Great Escape, they must also work to sustain this connection once the students return to their local church. YCM leadership places great importance on the ability to provide the students that attend with longitudinal spiritual growth, and the activities provided by the Great Escape are essential in this process.

Although The Great Escape is organized by YCM as opposed to the Presbyterian Church, YCM constantly works to keep the local churches connected throughout the retreat. While activities such as afternoon programs, evening programs, meals, and recreation are inclusive to all churches that attend, there are also more church specific activities that help foster a closer relationship between members of particular 
congregations. Each day the students begin with a quiet time session before breakfast, and this is essential in order for students to reflect on how the Holy Spirit is interacting with each individual student. Also after the afternoon program each church breaks up into small groups in order to further reflect on the message presented by the speaker, entertainer, or musician. Finally after the evening program the churches meet for Bed Time Talks that allow for the local church leadership to give their take on the daily message, and also give the students an opportunity to share how the spirit has been interacting with them throughout the week. The local church centered activities allow for each group to become more comfortable with each other as a more centralized charismatic body. The increased comfort level allows for the sharing of testimonies and also further opportunities for leadership to show how the power of Holy Spirit is working within their group.

While the programs, recreation, and time on the water slides provides a great deal of fun for the students at the Great Escape, it is in these smaller groupings that the message is given the chance to gain long-term sustainability. After five days of close interaction, both students and local church leadership are given relationships they can take back home with them. These activities have allowed the students to build the habit of fellowship with each other, and the opportunity to build similar youth groups or small groups once they return home. Since the Great Escape served as the setting for many of these students to first interaction with Jesus Christ and the power of the Holy Spirit, church leaders are encouraged to model their activities back at the local church in the mold of those at the Great Escape. The interplay creates a symbiotic relationship between the Great Escape and the local church. On one hand the churches receive the opportunity 
to form vibrant youth groups in the mold of the Great Escape, filled with potential future leaders of their church who have been filled with the Holy Spirit. On the other hand YCM receives continued happy participation from the local churches, and also an opportunity to fill their work crews and planning teams with cultivated charismatic products of the Great Escape.

The two models of spiritual activities utilized by the Great Escape create effective macro and micro opportunities for spiritual growth through the power of the Holy Spirit. The larger afternoon and evening programs in the Marina provide the students with a big picture understanding of YCM's charismatic message. On the one hand when the students are at these meetings they learn about the power of the divine Holy Spirit that will bring forth their conversion drama. On the other hand the smaller church specific activities such as quiet time, small groups, and BTTs allow for the students to recognize what stage they have reached in their own conversion process, and what further steps must be taken in order to reach a more fulfilling existence by way of a conversion drama. Both forms of spiritual activity place the power of the Holy Spirit at their core; as they enable the student to search for, recognize, and enthusiastically respond to their charismatic power source. Once the students, along with the leadership, have had this enthusiastic reaction to the Holy Spirit they are able to grow as spiritual products when they return to the local churches. In many ways the Great Escape serves as a spiritual microwave that is able to revolutionize the individual students religious existences, creating rejuvenated groups of leaders and students that will strengthen the dynamic of their local church. 
In order to psychologically understand the conversion dramas that take place while attending the Great Escape, it is important to study the work of Abraham Maslow. Although Maslow did not study organizations like the Great Escape, he did focus on the psychological effects within religious conversions. Maslow stated that religious conversions or awakenings were paths towards self-actualization. In terms of the Great Escape these students believe they are connecting with the Holy Spirit that is greater than thems. Roberto Asagioli later defined these types of connections as the transpernal, or something more than self. As the students at the Great Escape are progressing along in their conversion processes, they begin to desire an existence that is beyond their profane reality. Asagioli stated that when these desires are present individuals are more likely to experience a euphoric spiritual existence, and in this case that experience consists of an emotional response to the Holy Spirit. ${ }^{50}$

\section{THE ISSUE OF TIME AT THE GREAT ESCAPE}

The Great Escape has become a successful youth retreat thanks to its ability to give middle school students a spiritually enriching experience that sends them back to their local church having likely undergone their conversion drama. However just as the Great Escape organizers understand the brief period of time the students have at the retreat every year, they also understand that there is a small window of time for the students to attend the Great Escape. Students are eligible to attend during their middle school years, and this consists of time the students are going through sixth, seventh, and

\footnotetext{
${ }^{50}$ John R. Hinnels, The Routledge Companion to the Study of Religion, (New York City: Routledge, 2005), 172-173
} 
eight grade. If a student chooses to attend all three of these years they still only get the opportunity of fifteen days at this spiritually enriching retreat. In order for the organizers of the Great Escape to truly instill the message of the power of the Holy Spirit into these students, they must provide opportunities for involvement that exist after the students enter high school and college.

The main method utilized by The Great Escape in order to offer these opportunities comes through the many different leadership roles provided at each regional Great Escape site. The first forms of leadership are the student counselors who attend the Great Escape with each local church. These counselors are responsible for leading small groups, BTTs, and also closely monitoring the students throughout their time at the retreat. While some of these counselors may have relationships with students before arriving at the Great Escape, one of the more important roles for these leaders is known as win the right evangelism. Win the right evangelism consists of working to relate to the students while eating lunch, playing games during recreation, or even having a competition of who can go down the waterslide the most times. While these activities are not inherently religious, they are important in order for the students to feel a close connection to the counselors. Once the counselors have developed this relationship with the students, they are then able relate to the students when giving testimonies and having deep religious conversations. The main goal of the counselors is to cultivate an atmosphere of sharing and comfort, where the students will be willing to continue their conversion process. While the speakers, musicians, and entertainers are responsible for presenting the message of the Great Escape at the macro level, this message would not be 
able to truly reach the students without the work of the counselors who are compassionately engaged in the charismatic growth of their students.

The most essential form of student leadership at the Great Escape consists of the work crew, and these individuals range from early high school to college age. The majority of these students are selected from churches that send students to the Great Escape, as they are expected to be familiar with the daily activities before they arrive. These students are responsible running the daily recreational activities, performing skits at the afternoon and evening programs, and also building any apparatuses that will serve as backdrop for the retreat. These three activities will be based upon the theme chosen by YCM, meaning that in the past the work crew has been responsible for building pirate ships, western towns, and space ships in order to entertain the students.

While these previous roles for the work crew improve the outward appearance of the retreat, they are also essential in any behind the scenes work that needs to be done. Certain work crew members will be called on to be sound technicians, making sure that the charismatic message of the speakers and musicians is effectively broadcasted. While the evening speaker is responsible for sending the students out to reflect upon the power of the Holy Spirit, it is the work crew that is responsible for keeping the students on track and also returning them to the Marina when the time is right. The essential presence of the work crew is further evidenced at the end of the conversion night, as all individuals who accept the Holy Spirit into their hearts are given a candle and encouraged to raise it high showcasing presence of the Holy Spirit in the room. Once again while the speaker encourages the students to perform this act, without the work crew aiding in the process of lighting these candles this touching event would become a logistical nightmare. In 
order for the students to progress along in their conversion process and eventually seek the transpernal by means of the conversion drama; these work crew members must continue to work behind the scenes in order for everything to go off without a hitch. Since the majority of these workers previously experienced the Great Escape as students, they serve as effective peers. Always staying aware of what stage the students should be in their conversion processes.

Even though the students who comprise the work crew have passed the age of eligibility in order to attend the Great Escape, by serving in this different capacity the organizers of YCM are given the opportunity to further shepherd these students along in the latter stages of the conversion process. These students are not responsible for running small groups or BTTs; instead they are the entry-level form of Great Escape leadership. They are given the opportunity to work side by side with the planning team in order to see what truly needs to be done to make the retreat successful. At the Great Escape Southwind 2012 before each evening program the retreat director had a small conference with the members of the work crew who were responsible for the skits, recreation, and worship for the retreat. The conference gave the director an opportunity to provide advice, criticism, and overall praise for the work these youth workers were performing. The confidence from the planning team in the work crew once again showcases the symbiotic relationship between the Great Escape and the local churches it serves. On the one hand by continuing to send students to the serve on the work crew, the local churches receive students who are ready to become interns and youth leaders in their youth ministry program. On the other hand by continuing to send charismatically inspired work crew members back to the local church, YCM receives continued participation from the 
local churches it needs to survive as a retreat. The symbiotic relationship between this independent charismatic organization and the local Presbyterian Churches shows that YCM understands the importance of continuing to revitalize the mainline denominations from within.

While the counselors serve as those who are most intimately connected to the students who attend the Great Escape, and the work crew is responsible for the behind the scenes elements of the Great Escape; YCM also employs a large group of summer staff employees who travel to all different types of retreats throughout the summer. The YCM retreats that the summer staff travels to include Fun in the Son, Son Servants, and also the Great Escape. These individuals are responsible for filling in the necessary gaps in leadership depending on the specific retreat.

Overall the student leadership that serves the Great Escape is as essential as the students who attend the retreat during their middle school years. While the students are the charismatically infused products sent back to the local churches, the older student leadership provides YCM with the opportunity to further enrich the spiritual lives of those students who are especially passionate about the organization's message. Just as small groups and youth groups that started at the Great Escape can be implemented when the students and church leaders return to their local churches, the work crew, counselors, and summer staff are given the training in order to take on similar roles at their local church or at another YCM event. By continuing to cultivate these relationships the charismatic conversion that first took place when the leaders were students at the Great Escape can be perpetually supported by individuals who have partaken in a similar experience. The training allows for these charismatic Christians to place themselves in 
environments within their mainline denominations that will enable them to always respond enthusiastically to the Holy Spirit. Finally it cannot be understated that this also fills these mainline denominations with enthusiastic young leaders who will serve as the foundation for future generations of the church leadership.

Even though YCM is an independent organization outside of the Presbyterian Church, the forms of leadership that they create are meant to directly serve and enrich the Presbyterian Church of which they are a product.

\section{MOVING PAST GLOSSOLALIA}

When analyzing the theological core of the Great Escape, one sees that this organization is not overly concerned with glossolalia. There are many different activities, spiritual and profane in nature, that the Great Escape puts that into action in order to better enrich the religious existences of the students who attend. However none of these activities place speaking in tongues at their core. The lack of glossolalia within this charismatic organization can be tied back to YCM's attachment to the Presbyterian Church, a denomination that has throughout history looked askance towards the exercise of charismatic gifts. However it is more likely that the organizers of the Great Escape are acting in the mold of Peter and Paul, in that they are promoting the spiritual gifts of the Holy Spirit that will better enrich the lives of their students past their time at the retreat.

After attending the Great Escape, observers will notice that the main goal of this charismatic retreat is to prepare students to reenter their profane existences and local churches with the tools needed to become well-rounded Presbyterian citizens. These tools are not gained through a display of ecstatic speech, or even an overwhelming response to 
the presence of the power of the Holy Spirit in their lives. Instead these tools are gained through the leadership of the Great Escape aiding these students in their ability to enthusiastically respond to the Holy Spirit in their lives. When Peter delivered his first sermon on the day of Pentecost in the book of Acts, he delivered it in Aramaic, a language that all present could understand. The goal of his sermon was to announce the arrival of the Christian Church. While the presence of the Holy Spirit may have drawn the initial crowd, it was the enthusiastic sermon that allowed for the crowd surrounding Christianity to be sustained. Similarly when Paul wrote his letters to the Corinthians, his championed gifts of the Holy Spirit consisted of prophecy and love as opposed to glossolalia. In his mind while those who spoke in tongues were filled with the Holy Spirit in an especially dazzling way, those who witnessed their ecstatic utterances could glean little to no spiritual meaning out of their actions. Instead of promoting glossolalia, these influential New Testament figures encouraged the followers of Christ to respond enthusiastically to their initial charismatic conversion. It is through this enthusiastic response that the church growth and charismatic renewal can be found.

While YCM does not place Glossolalia at the center of its charismatic organization, they do reserve a special place for the power of the Holy Spirit. Charismatic Christians believe that in order for the church to trust its worldly actions, it must always keep the Holy Spirit at the center of all of its decisions. The motivating charismatic engine is what drives the church to act in the world. The third evening program for the Great Escape can be described as a form of Pentecostal Event at the retreat. The speakers, musicians, and leaders have been building to this evening, expecting a night full of conversion dramas. After the students return from their reflection, they are given a candle 
in order to represent the presence of the Holy Spirit at the retreat. While this does not include glossolalia, it is clearly a grand scale gift of the Holy Spirit.

However this is not where the event climaxes, for if it did there would be little purpose to it. After the students receive the power of the Holy Spirit, they must then be educated on how to utilize the Holy Spirit in order to govern their daily actions. Through the use of testimony, small group discussion, and other forms of local church fellowship these neophyte Christians are able to return to their churches as charismatically motivated members of the congregation. The goal of the Great Escape is not to create individuals outside of the church who have experienced the revitalizing Holy Spirit, but instead to create individuals who can take the power of the Holy Spirit and revitalize their local congregations. While the initial conversion drama is the lighting of the fire of Christ within their hearts, it is in latter stages of their conversion process that they are able to charismatically rejuvenate the main denomination of the Presbyterian Church.

\section{METONYMIC ELEMENTS OF THE GREAT ESCAPE}

Another element of the charismatic movement that is put into practice by the Great Escape is that of metonymy. While the students who attend the Great Escape are encouraged to put their faith into action in their profane lives and also within their local churches, the fact that the majority of the student's conversion dramas took place at the retreat places this event at the core of their spiritual existence. When these students have moved on from their time as students at the Great Escape, they will continue to identify their faith with that first candlelit response to the Holy Spirit from their youth. Whether these students move on to be YCM employees, Youth Ministry workers at their local 
church, or simply faithful members of the congregation, they will always find their religious strength in that first moment they were united with the Holy Spirit.

The use of metonymy is also useful to the youth leaders at the local churches. Once the students return home from the Great Escape, their time at the Great Escape will be remembered as a symbolic moment in their religious existences. If these youth leaders are able to transport the small groups back to local churches, form youth groups built from the BTTs, and also create a religious message for their students that fits the mold that first inspired them to be filled with the Holy Spirit; these leaders will then have the opportunity to harness the symbolic connection to the Great Escape. The power of the Great Escape as a symbol of the conversion drama is yet another tool given to the local churches by YCM. By continuing to hearken back to these original moments of charismatic inspiration, the church is able to continue the process of shepherding their youthful parishioners through adolescence.

While using the Great Escape as a charismatic symbol effectively keeps the youth of the congregation within the religious fold during their formative years, issues can become apparent if the local church is not completely in sync with the message of the Great Escape. In the next chapter, I focus not on YCM as a beacon of charismatic religious knowledge that it hopes to be, but instead upon the local churches that continually send students to the Great Escape each year. 


\section{CHAPTER 3: INTERACTIONS BETWEEN YCM AND THE PCUSA}

After gaining a firm scriptural and historical understanding of where charismatic organizations such as the YCM grew out of, and also understanding how exactly the Great Escape is put into place as an charismatic retreat that serves the Presbyterian Church; it is finally essential to analyze how YCM interacts with the Presbyterian Church within the United States of America. In order to fully grasp the relationship between these two ecclesiastical bodies one must first understand historical issues of leadership within the Presbyterian Church. Then it will be important to show how YCM and the churches that populate it choose to utilize servant leadership in order to remedy these traditional issues. It will also be important to show how these two organizations see leadership as more important than authority, and how this mindset attempts to provide avenues for future growth within YCM and the Presbyterian Church.

\section{SEARCHING FOR APPROPRIATE LEADERSHIP WITHIN PRESBYTERIAN ORGANIZATIONS}

As an organization, YCM hopes to provide a vital service to the Presbyterian Churches in the United States. The service consists of the charismatic education of the youth of the denomination, and the Great Escape provides a setting that allows for these students to experience the power of the Holy Spirit. While it cannot be doubted that the local Presbyterians hope that these students remain involved and invested members of the congregation, one quickly sees that issues of personal and corporate religious authority rise to the surface. While YCM was once officially under the umbrella of Presbyterians for Renewal, they are now only loosely affiliated with the Presbyterian Church, meaning 
that the charismatic and personal conversion drama undertaken by these students of the Presbyterian Church is being shepherded by an independent authoritative body.

There is an inherent contradiction within the idea of undergoing a personal religious experience at an independent retreat, and then after five days returning to an established Presbyterian denomination. While both the personal experience and the ecclesiastical body can be seen as vital to the growth of the parishioner, there can also be issues when each are left independent from each other. One youth minister from Chattanooga, Tennessee described a growing disconnect between the message of the Great Escape and that of his local Presbyterian Church that eventually led to him severing his churches ties with YCM. The individual actually once was the chief organizer of the Great Escape Southwind, and this led to a fruitful partnership with YCM. However once he chose to return full time to his Presbytery, he became less satisfied with his students experiences. While the students still greatly enjoyed their experiences at The Great Escape, once this particular leader was not in control of the retreat he became increasingly less satisfied with the speakers and musicians who were independently ministering to the youth of his congregation. In fact the leader felt that YCM focused too heavily on the emotions of his students, a method that he did not put into practice within his own youth ministry. When he was directing the Great Escape Southwind he was able to utilize these emotions in order to sustain his youth ministry, however once he was not in control of the material at the Great Escape this union of method and message ceased. After severing ties with the Great Escape by no longer populating the retreat with 
students, this pastor's relationship with his former YCM colleagues also withered. ${ }^{51}$

Although the personal religious growth experienced through YCM did not disappear, the particular religious authority figure simply could not bridge his churches theological divide with YCM.

According to Evelyn Underhill, established theology and personal spirituality, as well as the institution and the individual, are needed in order for the religious seeker to truly ground their faith. Even though personal religious experience is essential to one's faith, Underhill stressed that it was also necessary to remain attached a traditional church. ${ }^{52}$ The religious life of Evelyn Underhill can be analogous to those students who attend The Great Escape. As a member of the Catholic Church, Underhill often quarreled with the authoritative preaching of Pope Pius X. While she personally disagreed with Pope Pius X, she continually accepted the closed canon of the church. However at the same time she believed that divine was constantly revealing itself within the profane realm. Therefore without an infusion of personal religious experience, she did not feel that she could be a useful resource to her denomination. ${ }^{53}$

YCM is an independent organization, one that aids young students in their individual growth within the Christian religion. A further understanding of the Great Escape shows that while the students are at the retreat they undergo an important conversion drama in their lives, and also throughout the week they are instructed on how to better implement this experience into their daily religious existences within their

\footnotetext{
${ }^{51}$ Len Teague, interview by Nick Pearce, January 09, 2013.

${ }^{52}$ Grace Adolphsen Brame, "Evelyn Underhill : The Integrity of Personal Intellect and Individual Religious Experience as Related to Ecclesiastical Authority." Worship 68 (1994): 30.

${ }^{53}$ Brame, "Evelyn Underhill” 33.
} 
denominations. It is this interplay between the personal and corporate religion that can make YCM a resource for the local church. Underhill stressed that no religious experience exists for the sole benefit of the individual who originally experienced it. Instead the transformative experience also benefits the congregation that is able to learn from and model themselves off of the experience. In this sense once the Holy Spirit at the Great Escape transforms the students, these students are then required to reenter their local church in order to revitalize their religious communities. According to Underhill those who have undergone substantial personal religious growth are to be both solitary and social. In other words, once the charismatic personal conversion occurs, the convert must then utilize this growth in order to reenergize his/her local church. ${ }^{54}$ When a local Presbyterian Church is willing to accept the role YCM hopes to play within their youth ministry program, the results can be very positive. A youth minister in Ponte Vedra, Florida has been able to utilize the passion her students feel for the Great Escape and use it jump start her church's youth ministry. In her experiences the Great Escape has provided an effective gateway to continue to minister to her students as they enter middle school. By using the small groups formed as the Great Escape and also larger groups fashioned after the BTTs this particular church creates opportunities to remain connected to their students as they enter into an increasingly secular environment within the school systems. By allowing the students to hearken back to their time at the Great Escape in the

\footnotetext{
${ }^{54}$ Brame, "Evelyn Underhill" 44.
} 
summer, they provide an opportunity for spiritual growth that also gives the students an escape from their secular academic endeavors. ${ }^{55}$

Psychologists such as Maslow and Assagioli posited that after individuals experience a religious peak experience, or in the case of the Great Escape a conversion drama, they believe theirs is a more meaningful existence. However as this peak experience fades, so do the meaningful feelings. However this spiritual low can be remedied when the local church introduces elements of the Great Escape into their youth ministry. When the student is able to keep elements of their peak experience in their daily religious experience, they are more likely to avoid such spiritual valleys.

The organizers of the Great Escape place great importance in educating the youth of the Presbyterian Church, and this is also an important goal among the leadership within these local churches. If the churches are unable to successfully transmit their beliefs and authoritative teachings to the future generations of their church, then it risks the future of the local church. While The Great Escape provides an opportunity for the local churches to annually reenergize their young parishioners, the churches must also be aware of what type of energizing force is being instilled within these neophyte believers.

According to Justin Farrell, evangelical adolescents are entering a phase of their lives that will allow them the opportunity to become more liberal with their religious beliefs, making it even more important for the local congregations to make a serious religious impact on them before their teenage years. While this increased liberalness may lead to an increased feeling of identity among the students, it does not guarantee that they

\footnotetext{
${ }^{55}$ Kim Fornes, interview by Nick Pearce, January 08, 2013.
} 
will continue to feel connected to the church. Farrell focuses on factors such as delayed marriage, shifting moral authority, and the influence of higher education as reasons why evangelical students may become increasing liberal in their beliefs as they enter into adulthood. Delaying of marriage plays a part in the shifting beliefs of the evangelical student due to fact that marriage is a key factor in the renewing of ones religious obligations. According to Charles Berger one's belief structures are socially constructed, and the process of getting married and starting a family often leads to a renewed interest in being part of a church community. However if young evangelicals delay the process of marriage they are much more likely to keep their options open spiritually, eschewing the trend of rejoining a religious community. ${ }^{56}$

Another trend that factors into the liberalization of the young evangelicals is the choice to place the lessons learned through personal experiences over those given by the authority figures within one's church. Since these emerging adults are facing more diverse environments, they are also interacting with more individuals and lifestyles that are in conflict with the traditional belief structures set in place by their religious sources of authority. If these students are not armed with a deep charismatic connection to their religious faith during their teenage years, then their beliefs are more likely to be eroded thanks to their experiences with contrasting worldviews. ${ }^{57}$ Farrell also claims that higher education also plays a role in the liberalization of young evangelicals, as the students are

\footnotetext{
${ }^{56}$ Justin Farrell, "The young and the restless? The liberalization of young evangelicals." Journal For The Scientific Study Of Religion 50 (2011): 519.

${ }^{57}$ Farrell, "The young and the restless? The liberalization of young evangelicals." 520.
} 
more likely to leave their local churches and come into contact with even more worldviews that may erode the religious beliefs of their teenage years.

The issue of increased liberalization of the evangelical student makes the Great Escape an even greater resource to the local Presbyterian Churches, as it is a source of authority that provides the student with an opportunity to ground their worldviews with a strong charismatic energy source. However once again issues can arise when the authority provided by YCM clashes with the authority provided by the local Presbyterian churches.

The students of the Presbyterian Church that attend the Great Escape are entering into the formative years of their spiritual existences. Many of them are nearing high school and will soon come into contact external stimuli that will make it important for them to have religious authority figures in order to be appropriately shepherded towards adulthood. However this desire for authority is one that has plagued Protestantism since its inception. According to Robert E. Fitch, within Protestantism there is no actual seat of authority, instead there are only seats. Since Protestantism began as a revolt against authority, those who ascribe to it have often felt the need to be guarded against any form of overarching control. ${ }^{58}$ Although Protestants have claimed that true authority rests in the scriptures and the religious experiences, these divine forms of authority are not as easily called upon when one needs fellowship within the profane realm. The amount of individualism that is present within Protestantism also lead to the expectation that each

\footnotetext{
${ }^{58}$ Robert Elliot Fitch, "The seat of religious authority." Journal Of Religious Thought 5 (1948): 6.
} 
believer will appeal to certain sections of the Bible in order to guide their religious experiences, and they will appeal to them in a multitude of different ways. ${ }^{59}$

While an attachment to unifying system of leadership would provide Protestantism with the security of a set belief structure, it would also violate the original terms of the Protestant agreement. While the wide variety of Protestant beliefs creates the opportunity for a spiritual melting pot, the attachment to this variety also leads to the elements within that pot refusing to actually melt. These two elements in terms of the Great Escape attending students are YCM and The Presbyterian Church. Both of these organizations are looking to educate and mold the future of the denomination, but at times these two competing sources of authority can lead to a cancelling out of all authority for the students. The cancelling out of authority is another reason why at times local Presbyterian Churches cease their involvement with the Great Escape. One youth minister in Miami Springs ceased his involvement with the Great Escape as he simply did not believe that interacting with YCM provided authority that was consistent with the way he looked to minister to his students. After bringing a group of students to the Great Escape for over ten years this individual was experiencing a growing theological disconnect centered in demographic issues. His ministry focused on the Miami Springs Hispanic population, and the message of the Great Escape simply did not mesh with the needs of his ministry. ${ }^{60}$ In the case of this minister, these theological divides were centered in the fact that the needs of his students from an urban Miami setting did not

\footnotetext{
${ }^{59}$ John C. Bennett, "A Protestant conception of religious authority." Union Seminary Quarterly Review 7 (1951): 4.

${ }^{60}$ Pepe Mesa, interview by Nick Pearce, January 21, 2013.
} 
mesh with those from more suburban areas like Knoxville or Chattanooga. Instead of an evangelical melting pot, this individual ceased involvement based on fears that his students would leave the pot altogether. Since the Great Escape places such importance on sustaining a spiritual peak experience after the students leave the Great Escape, they also require a partnership from the local churches in order for the conversion drama to be sustained. However in the case of the Miami Springs youth minister the emotional message of the Great Escape did not mesh with his congregation.

In order for the ecclesiastical elements within Protestantism to begin to melt, Fitch states that an ironic infusion of Catholicism may be necessary. While not referring to a return to the Vatican, the idea of a Protestant culture defined by differences may bring forth more universality or catholicity. Instead of pretending that there are no important differences between the denominations, those within the realm of Protestantism would be better off acknowledging their differences in order to create strength through diversity. ${ }^{61}$ The creation of strength through differences can be incorporated into the relationship between YCM and the Presbyterian Church as both are Protestant organizations that are looking to be resources to the youth of the congregations. While YCM is hoping to infuse these students with a conversion drama that will aid them in their spiritual growth, The Presbyterian Church looks to be a center for the longitudinal growth of these students. A partnership between these two organizations is necessary in order for the spiritual growth of the youth of their congregation. The union can be seen within the churches that send students to the Great Escape, even though they do not always see eye to eye completely on how everything is presented at the retreat. While the

\footnotetext{
${ }^{61}$ Fitch, "The seat of religious authority." 7.
} 
minister from Chattanooga ceased his involvement based on being unsatisfied with the types of speakers involved, ${ }^{62}$ the minister from Ponte Vedra has often chosen to deal with disconnects in a different manner. The individual has at times been unhappy with the material presented by a YCM speaker, however in contrast she has been very satisfied with the amount of feedback YCM seeks from the local churches. While the material may not always be in line with the local church, this minister continues to work with the independent organization due to their ability to constantly work with her in order to remedy such issues. ${ }^{63}$

While complete acceptance of each others belief structures and organizational goals are not required in order to fit this model of Protestant catholicity, what is required is a agreement of cooperation between the independent YCM and mainline Presbyterian Churches that continually sends students to the Great Escape. If these organizations agree to disagree on smaller issues yet agree to cooperate in the spiritual education of the youth of the Presbyteries, then they will begin the process of battling the external stimuli that may erode the spiritual existences of their students.

The interplay between the charismatic YCM and the Presbyterian Church creates an interesting combination of traditional authority and individual authority by way of personal religious experiences. While the Presbyterian Church offers a form of concrete authority that has existed for many generations, the new religious vitality brought forth through the conversion drama at the Great Escape introduces personal authority into the

\footnotetext{
${ }^{62}$ Len Teague, interview by Nick Pearce, January 09, 2013.

${ }^{63}$ Kim Fornes, interview by Nick Pearce, January 08, 2013.
} 
equation. These students may have had a familiarity with their religion before attending the weeklong retreat; however thanks to the small group sessions, BTTs, Marina programs, and most importantly the response to the Holy Spirit they return to their local congregations with a much more personal connection to their faith. While they will attach importance to the scriptures and teachings of the larger church body, their acceptance of the Holy Spirit will likely be placed in a more central area in their religious memory. According to John C. Bennett within Protestantism traditional ecclesiastical authorities have tended to err on the side of conventionality and timidity, not wanting to rock the boat that has been carefully moving their parishioners along for generations ${ }^{64}$ However these inspired students are now reintroducing themselves into the congregation with hopes of continuing to be individually inspired by the Holy Spirit that they came into contact with at the Great Escape. The energetic reintroduction into the Presbyteries has been one of the most important factors leading to a certain Tampa, FL youth minister's continual involvement with the Great Escape. The minister stated that although many of his students are involved in the church all year long, he sees their time at the Great Escape as truly being important in terms of faith formation. Meaning that throughout the year he sees that his students are constantly referring back to their experiences at the Great Escape, and how it was the first time many of them truly felt a personal connection to their faiths. The metonymic connection to the Great Escape allows for his students to remain continually inspired by the Holy Spirit they first came into contact with at the Great Escape, allowing for the impact of this five day long retreat to sustain itself longitudinally. The sustainable connection to the Great Escape has also allowed this

${ }^{64}$ Bennett, "A Protestant conception of religious authority." 8. 
youth minister to have a connection with YCM that leads to him sending high school students back to the Great Escape as counselors and work crew members each year, as the spiritual attachment to the Great Escape does not dwindle as the students progress towards adulthood. ${ }^{65}$

When the local church provides opportunities for continual charismatic activity such as Great Escape inspired youth groups or small groups, then the students are likely to remain involved and satisfied with their traditional center of religious authority. Conversely if the local church does not provide such activities, then students will likely be less willing to maintain the same level of excitement pertaining to the Presbyterian Church. Although Bennett posits that individual religious expression without the aid of an established religious body can become increasingly secular, the church is still responsible for meeting the individual religious needs of those who attend it. ${ }^{66}$ Youth ministers who are willing to flavor their local youth ministry with elements of YCM and the Great Escape continually accept this responsibility.

Bennett also argues that the revolutionary ideas of individuals within the congregation have often been responsible for breaking the traditional forms of religious authority out of many a rut. In this sense it is not only the responsibility of the clergy and elders to provide opportunities for congregational growth, but also it is the responsibility of the congregation (in this case these charismatically inspired students) to rock the boat of conventionality and timidity in order to move the church forward. ${ }^{67}$ The symbiotic

\footnotetext{
${ }^{65}$ David Bonnema, interview by Nick Pearce, January 10, 2013.

${ }^{66}$ Bennett, "A Protestant conception of religious authority." 7.

${ }^{67}$ Bennett, "A Protestant conception of religious authority." 9.
} 
relationship between YCM and the local Presbyteries can also be put into practice between the students of the congregation and the leadership of the congregation. For those local churches that allow for the possibility, this inter-congregational combination of individual and communal ideas will allow for multiple opportunities for growth for all parties involved. One example of these types of opportunities can also be taken from YCM's involvement with the previously mentioned Tampa Presbytery. The youth minister at this church states that thanks to the church's involvement with the Great Escape they do not have to focus on the foundation of their student's faith as closely. After returning from the Great Escape their students have made a personal connection with the core of the Gospel message, meaning an acceptance of Jesus Christ as one's personal savior and a deep personal connection to their savior through the assumed presence of the Holy Spirit in the profane realm. Since these core beliefs of the Christian faith have already been cemented into the minds of the students, this youth minister is able to focus on issues of discipleship, service, and other issues relating to the growth of the local church. While this example refers to a local church that is completely in union with the theological message of the Great Escape, it still showcases the opportunities available to Presbyteries that are willing to partner with $\mathrm{YCM}^{68}$

The partnership between YCM and the PCUSA hopes to provide opportunities for the youth of the denomination to remain attached to their faith throughout adolescence. A 2009 Pew Forum poll on reasons that protestant youth either remain or leave their denominations during their formative years states that there are many reasons why students may leave the church. Thirty-nine percent of the youth who left the church did

${ }^{68}$ David Bonnema, interview by Nick Pearce, January 10, 2013. 
so based on their spiritual needs not being met, and twenty-nine percent of the students left due to dissatisfaction towards the atmosphere at worship ceremonies. ${ }^{69}$ The methods of YCM and the PCUSA provide avenues that can begin to bridge these gaps. By attempting to mold the churches youth ministry based on the model of the Great Escape, these churches are focusing directly on spiritual needs of their students. Also the model of the Great Escape worship service will add a charismatic atmosphere to the churches youth services.

However these two remedies are only achievable when the local church is willing to reach an ecclesiological union with YCM. The same Pew Forum poll stated that seventy-one percent of the students who left the church gradually drifted away from the church, and that fifty percent stopped believing in the churches teachings. ${ }^{70}$ Both of these statistics showcase an ecclesiology that can lead to the youth of the congregation to embrace apathy as opposed to enthusiasm. By introducing elements of the Great Escape into the local church, these Presbyterian leaders are choosing to actively shift their ecclesiology in order to keep the future leaders of the church involved. Keeping the students involved will also work to fix the issue of over twenty percent of the students feeling a lack of community with the local church. ${ }^{71}$

\footnotetext{
69 "Pew Forum: Faith in Flux: Religious Conversion Statistics and Changes in Religious Affiliation in the US" April 27th, 2009.

70 "Pew Forum: Faith in Flux: Religious Conversion Statistics and Changes in Religious Affiliation in the US".

71 "Pew Forum: Faith in Flux: Religious Conversion Statistics and Changes in Religious Affiliation in the US".
} 
Although the PCUSA has viewed charismatic Christianity negatively in the past, this partnership between YCM and the PCUSA provides avenues needed to improve the denominations relationship with its young parishioners.

\section{COMMUNICATION AND COOPERATION THROUGH SERVANT LEADERSHIP}

The issue of the spiritual shepherding of the students that attend the Great Escape is one that calls for great leadership and authority within these differing religious bodies. Although great leadership and authority are needed, these needs fall to the feet of a particular fashion of Christianity that has never had official forms of leadership or authority. While the scriptures and the religious experiences that are brought forth through the scriptures are sources of divine leadership, a middleman between The Holy Spirit and the students is greatly desired. According to Bob R. Agee, religious leadership can be defined as creating the appropriate attitudes, atmosphere, and actions that will bring about change within a person, group, or organization. ${ }^{72}$ Agee continues by stating that the lack of authority coming from the churches is the fault of both the congregation and the clergy, however the fault does not lie in the area of theological knowledge. Instead too often the congregation feels at odds with methods, motivations, and aspirations of their pastors and ministers. In the same vein the clergy often feel that they wish they could provide more of a leadership service to their congregation, however they simply do not know how to reach those who populate their gathering spaces. Once again

\footnotetext{
${ }^{72}$ Bob R. Agee, "Servant leadership as an effective approach to leadership in the church." Southwestern Journal Of Theology 43 (2001): 8.
} 
it does not appear to be an issue of theological acumen, but instead one based in the deficiency of communication and cooperation.

In order to remedy this deficiency in communication and cooperation, one finds that organizations such as YCM utilizes what it known as servant leadership. Certain churches who populate the Great Escape each summer also utilize this method, and whether or not they choose to do so is often directly proportional to said churches relationship with YCM. Servant leaders are those who chose to harness the power of the Holy Spirit in order to lead, as they believe, Jesus of Nazareth did. They mentor those in their congregation with a sense of love, peace, faithfulness, self-control, and patience. The form of servant leadership that symbolizes the leadership provided by the Great Escape truly inspired one of the youth ministers from Fort Lauderdale who values his relationship with the Great Escape. When he witnesses the way the Great Escape leadership works with his students he describes it as a labor of love. Meaning that the leadership, who are mostly volunteers, are solely motivated by their love for the students to which they are ministering. These individuals, including both YCM and this particular youth minister, are not focused on gaining a prestigious title within their respective religious environments. Instead they are focused on helping aid in the spiritual development of their students. ${ }^{73}$

However at the same time these leaders never lose track of the goals that they have set, meaning that they always place the needs of their parishioners at the center of their attentions. Simply providing a loving path towards charismatic growth for the students would not be sufficient if there was not an established end in the minds of the

\footnotetext{
${ }^{73}$ Nic Merchant, interview by Nick Pearce, January 22, 2013.
} 
leadership. According to Bob R. Agee the effectiveness of these individuals leadership is grounded in their ability to truly understand the needs of those who they have authority over, and at the same time always have a set goal in mind of where they want their congregation to go. ${ }^{74}$ Robert Greenleaf states that servant leadership requires that those with authority aspire to be servants to their congregation before they choose to lead said congregation. The same youth minister from Fort Lauderdale's relationship with the Great Escape symbolizes how both his church and YCM have a clear goal in mind that they use servant leadership in which to achieve. One of his favorite memories of working with the Great Escape is that both have a clear focus on aiding their students through their spiritual development as they progress towards adulthood. By partnering as servant leaders this Presbytery and YCM are able to foster the growth of their students from sixth to eighth grade in order for them to be ready to take on all the secular challenges they will face in high school and college. The fact that this church also continues to send students back to the Great Escape as both counselors and work crew members showcases how successful this partnership can be. ${ }^{75}$ Forrest Flaniken states that when a group, whether it be a congregation or group of students at the Great Escape, is under effective servant leadership they will eventually feel spiritually healthier, freer, more autonomous, and most importantly likely to become servants themselves. ${ }^{76}$

The focus on servant leadership can easily be seen while attending the Great Escape where the organizers look to reach their students through win the right

\footnotetext{
${ }^{74}$ Agee, "Servant leadership as an effective approach to leadership in the church." 9.

${ }^{75}$ Nic Merchant, interview by Nick Pearce, January 22, 2013.

${ }^{76}$ Forrest Flanikan, "Is the Bible relevant to servant-leadership?" Journal Of Applied Christian Leadership 1 (2006): 32-33.
} 
evangelism, and also remain ardently attached to their goal of aiding these students towards an acceptance of the Holy Spirit. There are churches that attend the Great Escape that willfully accept the baton of servant leadership after the five-day retreat. These churches recognize and embrace their charismatically enthused students and provide small groups, youth groups, and other form of Great Escape fashioned activities in order to further the growth of their students. By continuing to foster the charismatic growth of their students they will also be making them into more autonomous future leaders of their congregation. By instilling these students with a desire to serve their religious community they limit the risk of the student's interest in the church waning after the Great Escape ends. Instead of returning to the church and being relegated to the pew, churches continuing the method of servant leadership will work to foster continual religious growth. The choice to become servant leaders themselves within their own congregations begins for the Presbyterian Church from Ponte Vedra, Florida at the BTT after the commitment night on the third night of the Great Escape. The youth minister from this church states that a tradition has started for the oldest students to mentor the youngest students from the church, giving them advice and strategies from their own experiences in order to help sustain the reaction to the Holy Spirit they just experienced. By accepting the role of the servant leader at the Great Escape these young students are already preparing for their roles as future leaders at the Presbytery. Once again this showcases the power of the servant leadership championed by the Great Escape, as it allows for the organic creation of leadership that is ready to influence future generations of the congregation. ${ }^{77}$

${ }^{77}$ Kim Fornes, interview by Nick Pearce, January 08, 2013. 
On the other hand there are also churches that are not so willing to mold their youth ministry after YCM, and this can cause their students to feel increasingly separated from their charismatic conversion as the summer months dwindle away. The halting of the servant leadership provided by YCM comes from the local churches desire to have control over their own method of spiritual pedagogy, and perhaps not feeling completely comfortable with the emblazoned charismatic youths that are reentering their houses of worship. The above example is not saying that these particular local churches are not practicing servant leadership within their youth ministries. Since one of the main attributes of a servant leader is the ability to be goal oriented and to guide those who they lead toward that particular goal, when the goal of the Great Escape and of the local church are not in line with each other then suddenly there are two forms of servant leadership combating each other. While they both are hoping to guide their students along in their spiritual journey, they both have different methods in which they hope to do so. The leaders are both looking to initiate a path for their students, provide the structure and opportunity for which to traverse said path, and also bearing the emotions of their students in order to foster growth and limit risks. Since the growth being spoken of involves the salvation of the future of the congregation, it is not surprising that at times two leaders vying for the attention of one religious body could be at odds. ${ }^{78}$

Throughout the many decades that the Great Escape has been in existence many Presbyterian churches have joined the ranks, fortified the retreat with greater numbers each year, and some have also chosen to cease their involvement with this independent charismatic organization. While there are a multitude of churches that either champion

\footnotetext{
${ }^{78}$ Flanikan, "Is the Bible relevant to servant-leadership?" 34.
} 
YCM as a center for the growth of their youngest parishioners or have chosen to abandon the organization because of a lack of harmony with the goals presented by it; there are also Presbyterian Churches that have chosen to remain involved with YCM despite a lack of complete harmony. These individuals also serve as servant leaders who understand that the reward of their works is in the journey as opposed to the destination. ${ }^{79}$ Although these leaders may have differing methods and goals from the Great Escape, they understand that both look to help these students along the same path. Overall the larger goal is to make sure that these young Presbyterians remain passionately involved with the church as they march through adolescence and into adulthood. These leaders cherish the time their students spend at the Great Escape during the summer, and often allow them to return as counselors, work crew members, and summer staff after they grow past middle school age. However they also have their own goals specific to the local church that does not concern the Great Escape or YCM. This acceptance of differences creates a pedagogical timeshare agreement between the local church and YCM. An example of the timeshare can be witnessed when examining the relationship between the youth minister from Fort Lauderdale and YCM. The minister continues to send students to the Great Escape every summer and loves the reaction that he gets from the students both during and after they attend. However unlike earlier examples from Ponte Vedra and Tampa, this minister does not mold his youth ministry program based on the charismatic activities put into practice at the Great Escape. Instead of implementing Great Escape themed small groups or BTTs his youth ministry, he simply utilizes the passion from his students in order to implement the activities he feels best suits their particular ministry.

\footnotetext{
${ }^{79}$ Agee, "Servant leadership as an effective approach to leadership in the church." 18-19.
} 
The partnership shows that although communication and cooperation, or a complete lack thereof, is the norm, a loose confederation of evangelical organizations is also possible. ${ }^{80}$

Overall it appears that what ever type of servant leadership is engaged in by the local churches and YCM; communication and cooperation is necessary in order for there to be any sort of partnership.

\section{LEADERSHIP OVER AUTHORITY}

When analyzing the role of YCM and the local Presbyterian churches it appears that these two groups have worked to solve the issue of religious authority by leaving it out of the equation all together. While there are authoritative figures in the corporate offices of YCM and those serving as ministers and elders in the local churches, the individuals directly involved with the students appear to be more interested in being a source of leadership. The issue with authority within Protestant circles has always been that it has elements of coercion pulsing through it. Those fearing authority have never been ones to force obedience, constrain unique beliefs, or influence the direct actions of their parishioners. Instead they define leadership as encouraging and inspiring fellowship among believers, hoping not to constrain the uniqueness of the individual religious experience but instead foster it along in its growth.$^{81}$ The desire for leadership as opposed to authority is crucial to the growth the students who attend the Great Escape. The desire for leadership can be seen in the importance of the testimonies that are given by the

\footnotetext{
${ }^{80}$ Nic Merchant, interview by Nick Pearce, January 22, 2013.

${ }^{81}$ Franklin M. Segler, "Theological foundations for ministry." Southwestern Journal Of Theology 29 (1987): 6.
} 
speakers during the afternoon and evening programs, as well as those given by the church leaders during small groups and BTTs. While these two forms of leadership both hope to instill their religious message into the minds of their students, they do so by relating it to them through testimonies and personal accounts. They choose this method in order to not coerce the student into accepting their teachings, but instead so that they can better emotionally relate to the leadership of YCM and the local churches. By compassionately appealing to the hearts of the students they continually move the students along in their conversion process, and ultimately present a nurturing environment that can yield a conversion drama.

An interesting aspect of the leadership that is looking to mold the youth of the Great Escape is that the individuals making the closest emotional contact are not always classically understood members of religious authority. Within the Great Escape the work crew are usually in their high school and college age, and the counselors from the local churches are usually in the same age bracket. While the speakers, planning team, and head counselors are slightly older, it is in no way compulsory for them to have official titles such as minister or elder. Instead these figures are of value thanks to their ability to competently relate to the students they are working with. Win the right evangelism has no use if the leadership is unable to emotionally connect to the students. Being able to connect to students is far more important than ecclesiastical prestige or authority. The most important training is not earned from a seminary but is instead earned by the ability to emotionally connect with the students in order to guide them on their journey towards 
a conversion drama. ${ }^{82}$ The process of sharing stories, hardships, and successes between the leadership and the student takes place during and after the Great Escape is finished. Once again the goal of this leadership is not to appear as authority figures that are focused on earning a prestigious title within their church or organization. Instead they are focused on shepherding these students towards a decision to respond to the Holy Spirit, and then helping these students maintain the flame of charismata as they grow towards adulthood.

The focus on creating a personal connection with the students of the Great Escape fits in well with the idea of servant leadership. According to Avery Dulles this type of leadership gives the church a new relevance, new vitality, a new modernity, and a new sense of mission ${ }^{83}$ Instead of being reliant on figures of church growth such as attendance on Sunday, presence of a youth ministry, and a multitude of other ecclesiastically themed activities; this form of servant leadership goes past the idea of the parishioner as a number and instead invests in the emotional growth of those that inhabit the church and the retreat. This also fits the model of the charismatic movement as it strips down the ecclesiology to its core, where the most important element of ecclesiology is fellowship between those looking to respond to the Holy Spirit. This fellowship leads to connectedness of the congregation, and this connectedness continually creates future servants leaders to lead the future generations. The presence and eventual creation of new generations of servant leaders within the local church is one of the most substantial byproducts of the Great Escape. These individuals are able to

\footnotetext{
${ }^{82}$ Segler, "Theological foundations for ministry." 10-11.

${ }^{83}$ Segler, "Theological foundations for ministry."12.
} 
enable, encourage, and unite the local Presbyterian Churches as they return from the Great Escape with a zeal to make an impact. The nurturing leadership provides the local churches with a charismatic product that is able to recharge the local church. While the local church may not always agree fully with the charismatic methods of YCM, they are still the beneficiaries of the energetic students that return to them each summer.

\section{CONCLUSION}

It has been previously posited that the key to a healthy relationship between the congregation and the leadership, and also YCM and the local church, is cooperation and communication between all parties involved. The servant leadership instilled within the students at the Great Escape further strengthens these elements of a healthy relationship. These students bring back an element of team spirit to the church with hopes of gaining the trust of their leaders in order to further strengthen the rest of the congregation. They also aid in the transformation of their congregation, impressing many youth pastors with their desire to increase the number of students involved with The Great Escape and by proxy the youth ministry program at the local church. Most importantly these students assume responsibility for the future of both the Great Escape and their youth program. Since their local churches youth leaders recruited these students to attend the Great Escape, they return from the Great Escape with an emotional attachment to the organizing bodies that enabled their charismatic conversions. Overall the students and the leadership from the local churches returns from the Great Escape with a desire to 
cooperate and communicate with each other in order to be sources of renewal and growth within their religious communities. ${ }^{84}$

The leadership style that is championed by YCM and the students that attend it is one that is powered by emotional connection and personal relationships with those in which they are involved. While the right teachings are important in order to move the Presbyterian Church forward, these charismatically infused individuals are even more focused on right practice. Without assuming the role of a servant to their church, fellow students, leaders, and religion as a whole they would be violating the original terms of the Protestant agreement. Once again it is leadership that will provide ecclesiastical growth, and this leadership is based on being able to competently create emotional relationships with those who they wish to evangelize. While authority may be important for those at the top of Presbyterian totem pole, it is servant leadership that truly moves the congregation forward. ${ }^{85}$

\footnotetext{
${ }^{84}$ Segler, "Theological foundations for ministry." 17.

${ }^{85}$ Segler, "Theological foundations for ministry." 18.
} 


\section{CHAPTER 4: CONCLUSION}

\section{THE NEO-CHARISMATIC MOVEMENT}

Over the past year I have had the opportunity to work with YCM, and more specifically I have gained a more complete understanding of their summer retreat known as the Great Escape. I was originally interested in working with this organization due to my belief they were a charismatic organization within the Presbyterian Church.

Charismatic groups are very interesting due to their desire to remain within Christian denominations that they feel needs reformation. Those of the charismatic movement hope to revitalize the denominations that they believe have lost an essential connection to the power of the Holy Spirit, and they believe this is only possible through a partnership with mainline Christianity.

When analyzing YCM I began to realize that the designation of Neo-

Pentecostalism that is occasionally given to charismatic Christianity is very appropriate. Charismatic Christians are not simply taking the beliefs of the Pentecostals, ones that are focused on Glossolalia, spirit healing, and spirit baptism, and implementing them within their specific denomination. Instead the "Neo" or newness of this form of Christianity showcases the expansion based on cooperation that is necessary to remain attached to traditional Christian groups. Charismatic groups such as YCM do not place speaking in tongues and other pyrotechnic expressions of charismata at the center of their belief structures. Instead they focus almost exclusively on having an emotional reaction to the

presence of the Holy Spirit. This can be seen at the Great Escape on the third night of the retreat, when the students are led towards a conversion drama. YCM experiences charismata, or the gifts of the Holy Spirit, by leading their students to utilize the Holy 
Spirit as a guiding compass in their religious existences. This event does not feature any specific times for speaking tongues. Instead through a careful presentation of the Holy Spirit, these students are called to become new spiritual creations that are centered in a response to the Holy Spirit.

The lack of a display of linguistic pyrotechnics may lead some to believe that YCM is not truly a charismatic Christian movement. This supposed deficiency allows for YCM to continue having fruitful relationships with many Presbyteries throughout the United States. Their choice to express their charismatic beliefs in a more metaphorical way allows them to provide a spark to the denominations, while at the same time not become outcasts within their own group.

YCM is a unique example of this as they consider themselves to be an independent organization that used to be formal members of the PCUSA. Although YCM is now an independent organization that no longer uses the name Presbyterian, this organization still provides a service to the PCUSA. When the students of these Presbyteries return to their local churches they do not seek an ecclesiastical space to practice glossolalia. Instead these students return to their churches inspired by the charismatic Holy Spirit, hoping to also inspire the Presbyterian Church. Charismatic Christianity is defined by the desire to revitalize the mainline denominations of Christianity through the power of the Holy Spirit. By first revitalizing the future of the denominations with the power of the Holy Spirit, and then encouraging these neophyte charismatics to return and revitalize their local churches; YCM has discovered a method for the charismatic renewal of the Presbyterian Church that does not contain what is culturally understood to be an expression of charismata. This study has broadened my 
definition of charismatic Christianity. Even though certain charismatic groups may place speaking in tongues at the forefront of their belief structures, I am uncomfortable with the refusal to characterize a group as charismatic simply based on their choice to not practice glossolalia. YCM's work within the Presbyterian Church must be defined as charismatic, as they are inspiring the future generations of the Presbyteries with which they work with the power of the Holy Spirit.

Perhaps it would be best to define groups such as YCM as a neo-charismatic movement. These groups are moving past the concept of implementing Pentecostalism within the mainline denominations and instead changing the way they define charismata in order to better fit within the denominations they hope to revitalize. However showcasing these groups as revolutionary within the Pentecostal/charismatic sphere may not be appropriate, as they are actually connecting this modern movement to the works of the apostolic Christian Church. Earlier in this thesis I described the sermon delivered by Peter on the Day of Pentecost. A large crowd had gathered around the followers of Jesus who were speaking in foreign tongues, and beginning to mock the followers, as they believed them to be drunk. In order to counter the growing public sentiment about the controversial actions of the early Christians, Peter stood up and delivered what was believed to be first his first sermon. He claimed that the men before them were not drunk, but rather were simply filled with the power of the Holy Spirit. The book of Acts states that it was not the glossolalia that led to a great influx of believers into the Christian fold, instead it was the powerful intelligible sermon delivered by Peter.

Flash forward to the modern era and the same can be said of the students who attend the Great Escape. While these students are also emotionally responding to the 
Holy Spirit, the substantial work they are doing in their Presbyteries revolves around their charismatic drive to revitalize their churches. When they return they are not showcasing their ability to enthusiastically respond to the Holy Spirit through a form of religious performance. Instead they are using their enthusiasm to reenergize their churches youth ministries, creating new opportunities for fellowship throughout the year in the form of bible studies and small groups, and also working to make sure that their church sends more students to the Great Escape each summer. The power of this form of charismatic Christianity is not found in the infilling of the believer with the Holy Spirit, but in the Holy Spirit inspired actions of said believer. While the personal conversion drama lights the fuse of revitalization, it is the continual conversion process that allows for the rest of the congregation to see the fire burning.

The choice to express their gifts of the Holy Spirit through an enthusiastic reaction differentiates YCM from other charismatic movements, as they are utilizing their charismatic gifts in ways that the mainline denominations do not view negatively. Instead of playing the role of the early followers of Jesus and speaking in incoherent tongues, they are choosing to play the role of Peter who showcased his reaction to charismata in an intelligible format that can be digested by the rest of the congregation. This form of theological assimilation allows for the students of YCM to avoid becoming isolated within their denominations.

Another important New Testament figure in Paul provides these "Neocharismatics" with biblical support. While Paul acknowledged the significance of the Day of Pentecost as the moment the Holy Spirit entered the profane realm, he was also quick to limit the importance of glossolalia within the Christian religion. Paul saw this practice 
as a gift of spirit, but he did not believe that it had significant value as an evangelical resource. Paul famously put restrictions in place about how tongues were to be spoken in public worship, and also signified that prophecy and love were far more useful expressions of charismata. Paul's theological fingerprint can also be seen in the actions of YCM within the Presbyterian Church. YCM does not encourage their students to return to the Presbyteries and begin showcasing any form of religious prestige thanks to their newly minted conversion drama. Instead they are meant to return to the church and help others within their denomination experience the power of the Holy Spirit. Paul saw charismata as an effective signal of the power of the Holy Spirit within the profane realm, however he saw little use in the expression of charismata if it did not have direct evangelical implications.

If Peter and Paul walked into a Pentecostal/charismatic service and saw a group of believers speaking in unintelligible tongues, it is not likely they that they would view these actions as helpful to the cause of Christianity. However it is more likely that they would be in favor of the actions of the students who attend the Great Escape, as they are expressing their gifts of the spirit in ways that are for the sole purpose of revitalizing the church they inhabit. In this sense "Neo-charismatic" groups such as YCM are truly fulfilling the charismatic legacy that was approved by two of the original fathers of the Christian Church. This biblical foundation allows for these enthusiastic believers to leave the shadows of being a religious minority within their own denomination, without abandoning their charismatic goals. 


\section{THE CONTROVERSIAL ISSUE OF BRIEF EVANGELISM}

One element of the Great Escape that I have always found to be somewhat controversial is the brief amount of time the leadership of this organization actually has with the students that attend. Assuming that a student attends all three years they are eligible, they still are only exposed to the retreat for fifteen days during their time as adolescents. This controversy is compounded when one considers the foundational change that the organizers are looking to cause within the lives of the students, and with the public nature they choose to broadcast this goal. While it is not shocking that an evangelical organization is able to produce widespread conversion dramas through the use of powerful material, entertaining speakers, and a modern form of worship music, it is surprising that they are able help these students sustain their conversion throughout the rest of adolescence. Within psychological studies of religion the conversion drama has often been followed by an intense lack of religious fervor, as the emotion of the initial event simply cannot be sustained. However when discussing the effectiveness of the Great Escape with youth ministers who send students to it, a majority of them continue to use the Great Escape as the center of their ministry program. This shows the popularity of the Great Escape within the leadership, however the popularity amongst students can be seen through the fact that students also continue to be involved after middle school. Whether this consists of being a counselor, a work crew member, or on the summer staff, the message of the Great Escape appears to be one that can be sustained.

When looking for reasons as to why this message continues to hold firm in the minds of the students, I believe it is important to start with the relationships formed at the Great Escape. Although hundreds of students attend each Great Escape, the students 
continue to meet as churches while they are at the retreat. This means that although the macro message is delivered to the mass populace, the micro message is actually digested and put to use in a church specific setting. When the students leave the afternoon and evening programs, they are immediately placed in smaller church specific groups where the leadership can help the students theologically understand what they have just heard. These spiritual debriefings allow for the students to share their feelings with the adult leaders they will work with throughout the year, and they also allow for the adults to gain a firm understanding of how each student is progressing through the week. This close interaction forms close relationships between leadership and students, and I believe this is what keeps the students coming back to the Great Escape year after year. These relationships also help maintain the connection these students feel to the transpernal, or the connection to something greater than oneself. Since the students and leaders formed their relationships in coordination with the student's conversion drama, the leaders are able to aid in the sustaining of the students connection to the Holy Spirit.

In the section of my thesis where I described the issues in Protestant leadership, one of the issues discussed was the disconnect between the needs of the congregation and of the clergy. In order to bridge this disconnect cooperation and communication is needed from all parties involved. Through the process of forming close student/leader relationships forged through the charismatic message of the Great Escape, the churches that attend the Great Escape are able return to their Presbyteries feeling much more connected to each other. This connection once again brings forth the idea of metonymy for the churches that attend YCM retreats. The students feel a close symbolic connection to the Great Escape as the moment that their faith truly became personal to them. Since 
the local church leadership was also a part of the retreat that formed this metonymic connection to the Great Escape, the students will also feel closely connected to them. While the Great Escape is only a five-day retreat, the charismatic conversion that takes place within this brief period of time is taken back to the local churches with the students. As long as the leadership works to continue the work that is started at the YCM retreat, the fifteen-day exposure to the charismatic message can go a long way.

Another element present within the Great Escape that aids in the spiritual development of the students who attend after the Great Escape is over is servant leadership. Earlier sections of this thesis explained that servant leadership consists of the leader worrying less about being an authority figure and instead concerning themselves with the needs of those within their congregation. This can be seen at the Great Escape, as the organizers are mostly volunteers for the organization. The planning team, work crew, counselors, and summer staff are not concerned with ascending the ecclesiastical totem pole; instead they are there to focus completely on the religious growth of the students involved. Another element of servant leadership that is present at the Great Escape is the goal-oriented mindset of the leadership. From the second the students step foot on the Southwind site the leaders focus on aiding them in their conversion process, with the goal of eventually helping them experience a conversion drama.

While servant leadership is effective at the five daylong retreats, the leaders at the local churches also put it into place. Since the students have gone through a foundational change in their religious lives at the Great Escape, the responsibility then turns to the church leaders to help sustain these changes throughout the year. These two areas of 
servant leadership allow for the students to receive a year long charismatic education that is in line with both the goals of YCM and the local church.

The combination of the relationships formed at YCM and the servant leadership implemented by the YCM staff and the leaders from the Presbyterian Churches successfully solves the issue of the Great Escape only being a five day long retreat. Since the material, relationships, and activities are often continued after the students leave the retreat; it is more accurate to refer to this initial exposure as charismatic occupational training that can be continually implemented in the rest of the churches youth ministry programs throughout the calendar year. Once again the fact that the students are constantly reminded of their metonymic connection to their conversion drama that took place at the Great Escape, the local churches are provided with spiritually energized students that are ready to revitalize their ecclesiastical bodies from within.

\section{FINAL REMARKS}

The difference between Pentecostalism and the charismatic movement is that the latter has hoped to revitalize their traditional denominations from within by utilizing performative gifts of the Holy Spirit. At times the charismatic movements within particular denominations have not always been met with a positive response from the more traditional members of the congregation. The charismatic has often been painted as the victim in this scenario, looked at as the isolated minority within the church whose wants and needs cannot be met. However an earlier analogy of the melting pot that refuses to melt may be more accurate. Both the charismatic and the traditionalist within the congregation are both guilty of rigidly holding on to their own particular form of 
religious expression, refusing to reach across the isle and understand why the other is worshipping in the way that they are. Perhaps neither side is innocent, and both are guilty of refusing to melt into a more diverse religious body.

While all appears to be lost within this ecclesiastical gridlock, a solution can be found by observing YCM's interaction with the Presbyterian Church. Although the methods brought forward by YCM do not represent the charismatic movement as a whole, they do present a remedy for those within charismatic Christianity that feel isolated within their denominations. Instead of choosing to have their cake and eat it as well by wanting to stay in the denomination while also practicing a form of charismata such as glossolalia, YCM instead shifts their understanding of charismatic Christianity to a metaphorical response to the Holy Spirit. Instead of showcasing the arrival of the Holy Spirit through unintelligible speech, they react to the arrival of the Holy Spirit by becoming enthusiastic energy sources for the rest of the congregation. The students and leaders who attend the Great Escape return to their churches with the goal of making their presence felt, but they want this presence to signify a revitalized Presbyterian Church. This is clearly a new definition of the charismatic movement, but it also appears to be one that is more than just old wine in new skins. The new wine, or most likely grape juice within a Presbyterian Church, consists of the students of the Great Escape returning to their churches and shining the light of Holy Spirit though actions that makes them servant leaders for the rest of the congregation. By showcasing their charismata through service, revitalizing energy, and a desire to improve all other elements of the Presbyterian Church, these Great Escape sponsored students are truly doing the reformative work desired by the charismatic movement with Christianity. 
Finally one of main goals of the charismatic movement as a whole within Christianity is to battle the believed increased secular nature of their religion. In hopes of revitalizing Christianity, those who favor charismatic Christianity hope to express their religion in a way that models the church under the leadership of Peter and Paul. Although the motives of this movement are pure in nature, their desire to express their religion through performative gifts of the spirit have often caused charismatic Christians to become outcasts within their own denominations. The reason why YCM is important to the charismatic movement is that they are willing to mold their expression of charismata in ways that are digestible to mainline Christianity, showcasing themselves as a group that can bring both Pentecostals and charismatic Christians out of the shadows of their denominations.

Another important element of YCM to both the Presbyterian Church and society as a whole is that this group has chosen to focus on the youth of America. Although YCM stresses the importance of returning to the Presbyteries after the students leave the Great Escape, the students are placing their experiences at the Great Escape at the core of their religious existences. This pushes the local church to mold their youth ministries to fit the charismatic conversion brought forth by the Great Escape. It is also important to remember that $\mathrm{YCM}$ is an evangelical organization that motivates its students to invite more of their friends every year. While many of these new students come from the Presbyteries, they are also likely to want to bring their non-Christian friends to this spiritually enriching and fun retreat. The independent nature of the Great Escape allows for its charismatically infused students to reach out into the secular world as well as the religious world. Not only is YCM infusing a digestible form of charismatic Christianity 
into the Presbyterian Church, but also into the secular environments that its students inhabit throughout the year.

The reason that the Great Escape exists is to infuse the youth of the United States with the power of the Holy Spirit, and the charismatic results will be felt by both religious and secular organizations. 


\section{BIBLIOGRAPHY}

Agee, Bob R. "Servant leadership as an effective approach to leadership in the church." Southwestern Journal Of Theology 43, no. 3 (June 1, 2001): 7-19. ATLA Religion Database with ATLASerials, EBSCOhost (accessed February 6, 2013).

Balmer, Randall, and Lauren F. Winner. Protestantism in America. New York City: Columbia University Press, 2002.

Balmer, Randall, Jon Butler, and Grant Wacker. Religion in American Life. New York City: Oxford University Press, 2003.

Bennett, John C. "A Protestant conception of religious authority." Union Seminary Quarterly Review 7, no. 1 (November 1, 1951): 3-10. ATLA Religion Database with ATLASerials, EBSCOhost (accessed February 6, 2013).

Bonnema, David. Interview by Nick Pearce. January 10, 2013.

Brame, Grace Adolphsen. "Evelyn Underhill : The Integrity of Personal Intellect and Individual Religious Experience as Related to Ecclesiastical Authority." Worship 68, no. 1 (January 1, 1994): 23-45. ATLA Religion Database with ATLASerials, EBSCOhost (accessed February 6, 2013).

Dominy, Bert B. "Spirit, Church, and Mission : Theological Implication of Pentecost." Southwestern Journal Of Theology 35, no. 2 (March 1, 1993): 34-39. ATLA Religion Database with ATLASerials, EBSCOhost (accessed November 12, 2012).

Farrell, Justin. "The young and the restless? The liberalization of young evangelicals." Journal For The Scientific Study Of Religion 50, no. 3 (September 1, 2011): 517532. ATLA Religion Database with ATLASerials, EBSCOhost (accessed February 6, 2013).

Fitch, Robert Elliot. "The seat of religious authority." Journal Of Religious Thought 5, no. 1 (September 1, 1948): 6-14. ATLA Religion Database with ATLASerials, EBSCOhost (accessed February 6, 2013).

Fitzmyer, Joseph A. "The ascension of Christ and Pentecost." Theological Studies 45, no. 3 (September 1, 1984): 409-440. ATLA Religion Database with ATLASerials, EBSCOhost (accessed November 12, 2012).

Flaniken, Forrest. "Is the Bible relevant to servant-leadership?." Journal Of Applied Christian Leadership 1, no. 1 (June 1, 2006): 32-39. ATLA Religion Database with ATLASerials, EBSCOhost (accessed February 6, 2013).

Fornes, Kim. Interview by Nick Pearce. January 08, 2013. 
Hamilton, Malcolm, Stephen Hunt, and Tony Walter. Charismatic Christianity:Sociological Perspectives. New York City: St. Martin's Press, Inc., 1997.

Hendrix, Scott H. "Charismatic renewal : old wine in new skins." Currents In Theology And Mission 4, no. 3 (June 1, 1977): 158-166. ATLA Religion Database with ATLASerials, EBSCOhost (accessed December 4, 2012).

Hinnells, John R. . The Routledge Companion to the Study of Religion. New York City: Routledge, 2005.

Martin, Ira Jay. "Glossolalia in the Apostolic Church." Journal of Biblical Literature. 62. no. 2 (1944): 123-130.

Merchant, Nic. Interview by Nick Pearce. January 22, 2013.

Mesa, Pepe, Interview by Nick Pearce, January 21, 2013.

O'Toole, Robert F. "Acts 2:30 and the Davidic covenant of Pentecost." Journal Of Biblical Literature 102, no. 2 (June 1, 1983): 245-258. ATLA Religion Database with ATLASerials, EBSCOhost (accessed November 12, 2012).

Painter, John. "The charismatic movement and the New Testament." Journal Of Theology For Southern Africa no. 7 (June 1, 1974): 50-60. ATLA Religion Database with ATLASerials, EBSCOhost (accessed December 4, 2012).

Presbyterians For Renewal, "History." Accessed February 3, 2013. http://www.pfrenewal.org/about-us/history.

Poewe, Karla O. "The Charismatic Movement and Augustine : The Challenge of Symbolic Thought in the Modern World." Pneuma 11, no. 1 (March 1, 1989): 2135. ATLA Religion Database with ATLASerials, EBSCOhost (accessed December 4, 2012).

Segler, Franklin M. "Theological foundations for ministry." Southwestern Journal Of Theology 29, no. 2 (March 1, 1987): 5-18. ATLA Religion Database with ATLASerials, EBSCOhost (accessed February 6, 2013).

Smylie, James H. "Testing the spirits in the American context : great awakenings, pentecostalism, and the charismatic movement." Interpretation 33, no. 1 (January 1, 1979): 32-46. ATLA Religion Database with ATLASerials, EBSCOhost (accessed December 4, 2012). 
Sontag, Frederick E. "Should theology today be charismatic." Journal Of The Evangelical Theological Society 30, no. 2 (June 1, 1987): 199-203. ATLA Religion Database with ATLASerials, EBSCOhost (accessed December 4, 2012).

Stephanou, Eusebius A. "Charismata in the early church Fathers." Greek Orthodox Theological Review 21, no. 2 (June 1, 1976): 125-146. ATLA Religion Database with ATLASerials, EBSCOhost (accessed November 12, 2012).

Swete, H.B. "The Prophets in the Christian Church." The Biblical World. 26. no. 3 (1905): 202-214.

Teague, Len. Interview by Nick Pearce. January 09, 2013.

The Pew Forum on Religion and Public Life, "Pew Forum: Faith in Flux: Religious Conversion Statistics and Changes in Religious Affiliation in the US." Last modified April 27th, 2009. Accessed April 2, 2013. http://www.pewforum.org/Interactive-Reasons-for-Joining-Reasons-forLeaving.aspx.

Unger, Merrill Frederick. "Significance of Pentecost." Bibliotheca Sacra 122, no. 486 (April 1, 1965): 169-177. ATLA Religion Database with ATLASerials, EBSCOhost (accessed November 12, 2012).

VanderKam, James C. "Covenant and Pentecost." Calvin Theological Journal 37, no. 2 (November 1, 2002): 239-254. ATLA Religion Database with ATLASerials, EBSCOhost (accessed November 12, 2012).

Votaw, Clyde Weber. "The Great Day of Pentecost." The Biblical World. 19. no. 1 (1902): 47-50.

Youth Conference Ministries, "Our Mission and Vision." Accessed February 3, 2013. http://ycmhome.org/about/. 